\title{
Discovery of an albite gneiss from the Ile de Groix (Armorican Massif, France): geochemistry and LA-ICP-MS U-Pb geochronology of its Ordovician protolith
}

\author{
Afifé El Korh $\cdot$ Susanne Th. Schmidt • \\ Michel Ballèvre $\cdot$ Alexey Ulianov $\cdot$ Olivier Bruguier
}

Received: 4 April 2011/Accepted: 28 October 2011/Published online: 19 November 2011

(C) Springer-Verlag 2011

\begin{abstract}
For the first time, an albite orthogneiss has been recognised and dated within the HP-LT blueschist facies metabasites and metapelites of the Ile de Groix. It is characterised by a peraluminous composition, high LILE, Th and $\mathrm{U}$ contents, MORB-like HREE abundances and moderate $\mathrm{Nb}$ and $\mathrm{Y}$ values. A U-Pb age of $480.8 \pm 4.8$ Ma was obtained by LA-ICP-MS dating of zircon and titanite. It is interpreted as the age of the magmatic emplacement during the Early Ordovician. Morphologically different zircon grains yield late Neoproterozoic ages of 546.6-647.4 Ma. Zircon and titanite $\mathrm{U}-\mathrm{Pb}$ ages indicate that the felsic magmatism from the Ile de Groix is contemporaneous with the acid, pre-orogenic magmatism widely recognised in the internal zones of the Variscan belt, related to the Cambro-Ordovician continental rifting. The magmatic protolith probably inherited a
\end{abstract}

\section{A. El Korh $(\bowtie) \cdot S$. Th. Schmidt}

Department of Mineralogy, University of Geneva,

Rue des Maraîchers 13, 1205 Geneva, Switzerland

e-mail: afife.elkorh@geo.unibe.ch

Present Address:

A. El Korh

Institute of Geological Sciences, University of Bern,

Baltzerstrasse 1+3, 3012 Bern, Switzerland

M. Ballèvre

Geosciences Rennes (UMR CNRS 6118),

University of Rennes 1, 35042 Rennes Cedex, France

\author{
A. Ulianov \\ Institute of Mineralogy and Geochemistry, \\ University of Lausanne, Anthropole, 1015 Lausanne, \\ Switzerland \\ O. Bruguier \\ Geosciences Montpellier (UMR CNRS 6250), \\ University of Montpellier 2, 34095 Montpellier Cedex 05, \\ France
}

specific chemical composition from a combination of orogenic, back-arc and anorogenic signatures because of partial melting of the Cadomian basement during magma emplacement. Besides, the late Devonian U-Pb age of $366 \pm 33 \mathrm{Ma}$ obtained for titanite from a blueschist facies metapelite corresponds to the age of the HP-LT peak metamorphism.

Keywords Cambro-Ordovician rifting - Ile de Groix . Incompatible trace elements · In situ U-Pb geochronology · LA-ICP-MS · Albite orthogneiss · Titanite · Variscan orogeny $\cdot$ Zircon

\section{Introduction}

The Variscan belt, of late Palaeozoic age, results from the collision between two major continental domains, namely Laurussia and Gondwana. These continents were separated by a huge oceanic domain, the Rheic Ocean (e.g. Matte 2001; Nance et al. 2010). Oceanic sutures within the Variscan belt can be identified using ophiolitic complexes and/or highpressure terranes, the latter deriving either from subducted oceanic crust or from subducted continental crust.

Remnants of ophiolitic complexes are scattered throughout the Variscan belt, from Poland to Spain and Portugal. Ages obtained for these complexes cluster in three groups. The first one consists of Late Cambrian-Early Ordovician complexes, such as the Chamrousse (Pin and Carme 1987; Ménot et al. 1988) and the Vila de Cruces Ophiolites (Arenas et al. 2007). A second group comprises ophiolite complexes with Early Devonian ages, i.e., about 400 Ma old, such as Central Sudetic ophiolites (Kryza and Pin 2010), the Lizard Complex in SW England (Clark et al. 1998) and the Careón Ophiolite in NW Spain (Díaz Garcia et al. 1999; Pin et al. 2002; Sánchez Martinez et al. 2007). 
The third group, Early Carboniferous in age, is best represented by the Beja-Acebuches Complex (Azor et al. 2008).

In western France, an intimate association of blueschist facies metabasites with metapelites has been recognised on the Ile de Groix and at the Bois de Céné klippe. A probable equivalent in the Variscan belt of NW Spain may be the "upper, oceanic unit" of the Malpica-Tuy Complex, because the Ceán schists and associated mafic rocks show similar lithologies and P-T evolution (Rodríguez Aller 2005; LópezCarmona et al. 2010). Although both complexes are recognised as oceanic in character, their interpretation remains debatable. Because of the lack of ultramafics and metagabbros, and the overall dominance of metapelites, they cannot be interpreted as typical ophiolite complexes. More realistic models could be the formation of narrow, intracontinental rifts with a strongly attenuated continental crust or accretionary prisms associated with ophiolite subduction of a narrow oceanic basin. Another source of uncertainty in the interpretation of the above complexes is the lack of age constraints on the protoliths. This is because felsic metaigneous bodies, containing magmatic minerals like zircon that potentially preserve protolith ages despite the HP metamorphic overprint, have not been found up to now.

For the first time, an albite orthogneiss has been recognised on the Ile de Groix. This paper focuses on its detailed geochemistry and $\mathrm{U}-\mathrm{Pb}$ zircon and titanite geochronology by LA-ICP-MS. In the latest 10 years, LA-ICP-MS became a widespread tool for $\mathrm{U}-\mathrm{Pb}$ dating of zircons. The LA-ICP-MS technique has recently been applied for titanite geochronology as well (e.g. Simonetti et al. 2006; Storey et al. 2006). Titanite is a frequent mineral in many magmatic and metamorphic rocks; its lattice can incorporate significant amounts of $\mathrm{U}$ and $\mathrm{Th}$. In situ dating of titanite is a promising technique for metamorphic rocks, since titanite can be assigned to the different stages of the metamorphic P-T cycle based on textural criteria (Frost et al. 2000).

The geochemical and geochronological data are used to characterise the geotectonic setting of the magmatic protolith in order to understand its association with oceanic metabasalts and continental-derived metapelites. For the first time, the age of a protolith has been accurately determined on the Ile de Groix. Additionally, the peak metamorphic titanite has been dated in a blueschist facies metapelite. The results have critical significance for the geodynamic history of the Early Palaeozoic oceanic domains involved in the Variscan orogeny.

\section{Geological context}

\section{The Ile de Groix klippe}

The Armorican Massif represents an important witness of the Variscan orogen in Western Europe. Three tectonic domains were described based on the degree of deformation and metamorphism during the Variscan orogeny. The boundaries between the domains are defined by the North Armorican and the South Armorican shear zones. The North Armorican Domain consists of undeformed or weakly deformed sediments of folded Cambrian to Carboniferous age (Robardet 1981), overlying a Precambrian basement, strongly deformed during the Cadomian orogeny (620-530 Ma) (Chantraine et al. 2001; Ballèvre et al. 2001; Brun et al. 2001). The Central Armorican Domain is characterised by a basement dominated by a thick sequence of alternating siltstones and sandstones with less frequent conglomerates and mudstones of late Precambrian-Early Cambrian age (Le Corre 1977). Clastic sediments of Ordovician to Carboniferous age (Guillocheau and Rolet 1982) are deposited upon the basement. In the South Armorican Domain, the Precambrian basement and its Palaeozoic cover have been strongly affected by deformation and metamorphism. The South Armorican Domain is characterised by the presence of a large amount of preVariscan orthogneisses (e.g. Jégouzo et al. 1986; Gapais et al. 1993; Chantraine et al. 1996; Le Hébel et al. 2002a, b), mainly consisting of Early Ordovician metagranitic rocks and acid volcanic and volcanoclastic rocks. The Ordovician metavolcanic rocks, known as the "Porphyroid Nappe" (Le Hébel et al. 2002a, b), constitute a complex tectonic unit, which was affected by HP-LT metamorphism during the early stages of the Variscan orogen. Different protoliths were suggested to explain the origin of Ordovician metagranites, from calc-alkaline subduction-related granites to anorogenic alkaline granitoids and collisional S-type granites (e.g. Jégouzo et al. 1986; Guerrot et al. 1997; Ballèvre et al. 2002).

Similarities of sedimentary sequences between the Central Armorican Domain and the Central Iberian Zone, as well as between the South Armorican Domain and the Galicia-Trás os Montes Zone (Spain), allowed defining the Ibero-Armorican arc (e.g. Cogné 1971; Bard 1971; Ballèvre et al. 1992), an important area of the Variscan orogen. Ordovician magmatism has been described on both sides of the Ibero-Armorican arc (Bea et al. 2007; Ballèvre et al. 2009), as well as along the main Variscan sutures, from the Sudetes to Iberia (e.g. Guerrot et al. 1997; Crowley et al. 2000; Valverde-Vaquero and Dunning 2000; Ballèvre et al. 2002; Mazur et al. 2004; Bea et al. 2007).

The Ile de Groix belongs to the South Armorican Domain (Fig. 1) and corresponds to a well-known HP-LT blueschist klippe (Audren et al. 1993) of about $60-70 \mathrm{~km}$ long and 10-15 km wide (Audren and Lefort 1977), located off the southern coast of Brittany. It is interpreted as the remnant of a Palaeozoic accretionary complex (Ballèvre et al. 1998), formed during subduction and exhumation of an oceanic crust and its sedimentary cover (Bernard- 


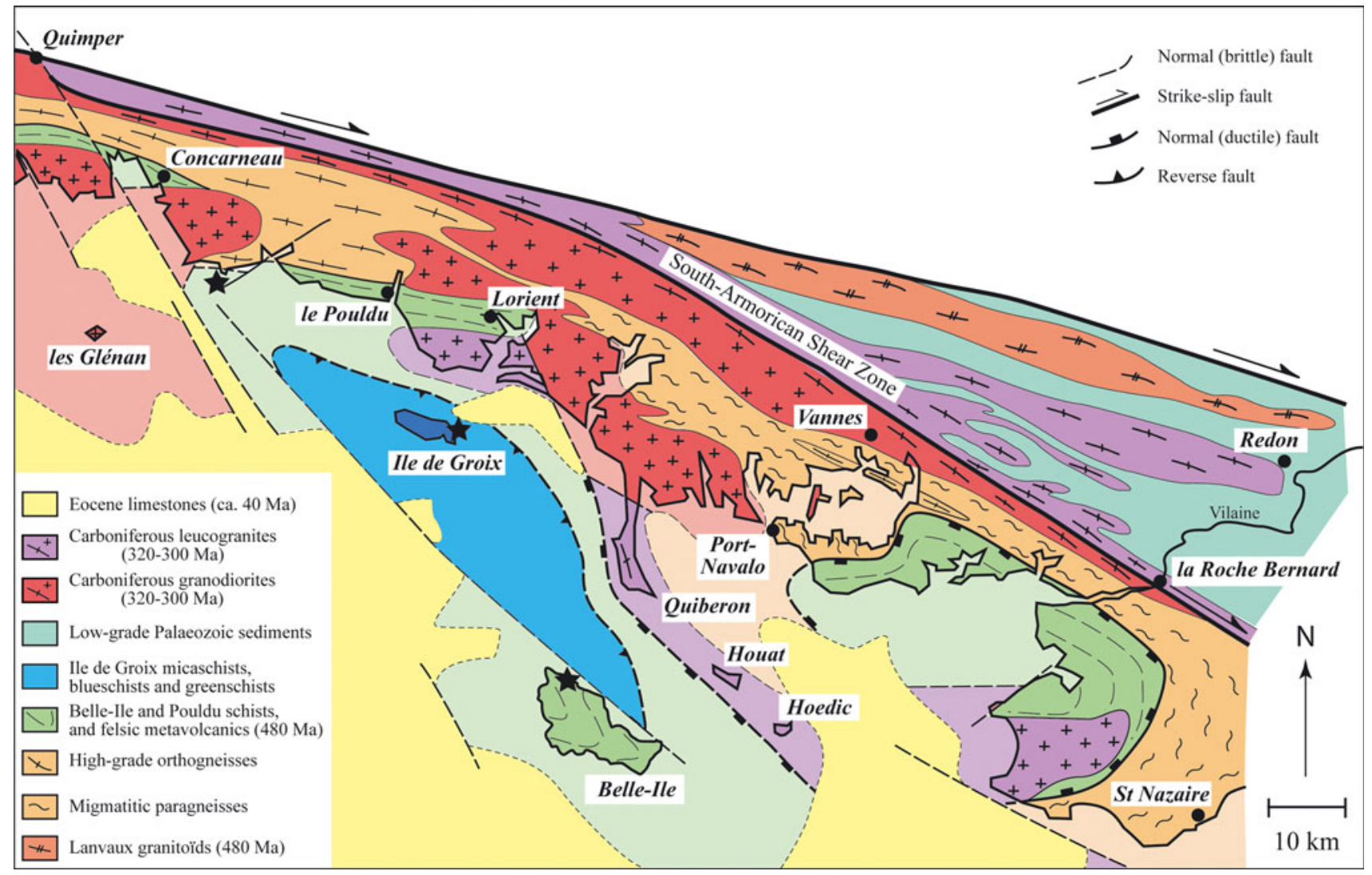

Fig. 1 Geological map of the South Armorican Domain. The three stars represent the felsic metavolcanics with Cambro-Ordovician ages (Ile de Groix, this study; Belle-Ile, Ballèvre et al. 2011; Pouldu Schists, Béchennec et al. 1997)

Griffiths et al. 1986; Bosse et al. 2002; El Korh et al. 2009). The HP-LT event is considered to have occurred in the early stages of the Variscan orogen, i.e., during the late Devonian-Early Carboniferous period (Bosse et al. 2005).

Metamorphic and deformation history

HP-LT rocks of the Ile de Groix mainly consist of $80 \%$ metapelites and $20 \%$ metabasites, intercalated at all scales (Fig. 2). Basic bodies, sometimes with isoclinal folds or boudinage, outcrop as centimetric to metric lenses to layers of several tens of metres (Audren et al. 1993; Bosse et al. 2002; Ballèvre et al. 2003). Different studies have classified the metamorphic rocks of the Ile de Groix into different groups according to the nature of their protolith (Triboulet 1974; Bernard-Griffiths et al. 1986; Audren et al. 1993; Bosse et al. 2002; El Korh 2010; El Korh et al. 2009, 2011): massive metabasites, banded volcano-sedimentary rocks and metapelites.

Two metamorphic events were described based on petrological observations in the metapelites (Djro et al. 1989, Bosse et al. 2002) as well as in the basic rocks (e.g. Triboulet 1974; Carpenter 1976; Barrientos 1992; Schulz et al. 2001; Ballèvre et al. 2003): a blueschist-eclogite facies metamorphism (M1) related to subduction, and a greenschist facies overprint during the exhumation (M2). Eclogite and blueschist facies rocks are dominant in the eastern part of the island, while the western part is mainly composed of greenschist facies rocks (with blueschist facies relics).

Previous studies have proposed that the metamorphic zonation results from a metamorphic gradient with $\mathrm{P}-\mathrm{T}$ conditions varying continuously from West to East and where the metamorphic domains are separated by "isograds" (Triboulet 1974; Carpenter 1976; Quinquis 1980; Djro et al. 1989; Schulz et al. 2001). The existence of a "garnet isograd" (Carpenter 1976; Quinquis 1980) is refuted by the presence of garnet in both metapelites (Bosse et al. 2002) and metabasites (El Korh 2006; El Korh et al. 2009) from the two parts of the island. In the western part of the island, garnet in metabasic rocks is strongly pseudomorphosed and not easily recognised. Other authors have defined two metamorphic units separated by a ductile thrust dividing the island into the Upper Unit or highpressure zone $\left(1.6-1.8 \mathrm{GPa}, 450-500^{\circ} \mathrm{C}\right.$ in micaschists and $1.8-2.0 \mathrm{GPa}, 450^{\circ} \mathrm{C}$ in metabasites) in the eastern part of the island and the Lower Unit or lower pressure zone (1.4-1.6 GPa, $400-450^{\circ} \mathrm{C}$ in micaschists) in the West 
Fig. 2 Geological map of the Ile de Groix (after Audren et al. 1993; Bosse et al. 2002; El Korh et al. 2009). *The convex beach "Plage des Grands Sables" moved because of the currents. 1993 corresponds to its position on the geological map by Audren et al. (1993), while 2004 refers to its position based on our field observations

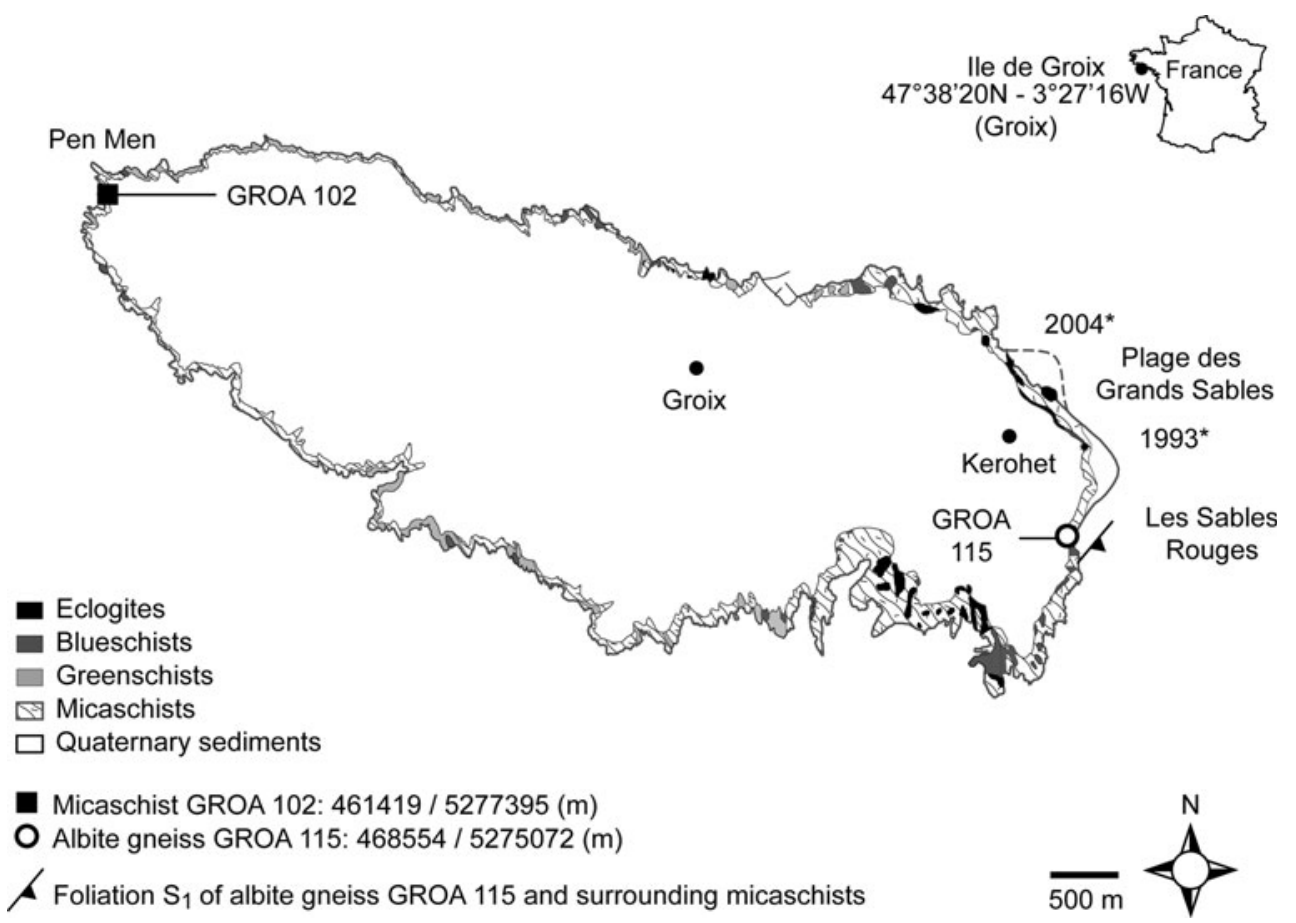

(Bosse et al. 2002; Ballèvre et al. 2003). Using THERIAKDOMINO, the HP peak metamorphic conditions were estimated to be $1.6-2.5 \mathrm{GPa}$ and $550-650^{\circ} \mathrm{C}$ in eclogite and $1.7-2.3 \mathrm{GPa}$ and $450-525^{\circ} \mathrm{C}$ in blueschists from the eastern part of the island (El Korh et al. 2009). These P-T conditions correspond to the transition from blueschist to eclogite facies in an intermediate thermal regime of subduction zone metamorphism. High-pressure parageneses are overprinted essentially by chlorite, albite and magnetite in micaschists (Bosse et al. 2002), and by barroisite, actinolite, albite, chlorite and magnetite in basic rocks (Ballèvre et al. 2003; El Korh et al. 2009).

Two main structural domains were recognised on the island (Cogné et al. 1966; Boudier and Nicolas 1976; Carpenter 1976; Quinquis 1980; Quinquis and Choukroune 1981) and correspond to the metamorphic units. The eastern part is characterised by flat-lying or gently dipping foliations and a NNW-SSE-trending stretching lineation, whereas a kilometre-scale N130-140-trending antiformal fold is present in the western part. Two main phases of deformation were described with regard to the metamorphic history (Quinquis and Choukroune 1981). The progressive deformation $D_{1}$ responsible for the blueschist facies foliation $S_{1}$ took place during the prograde path and the peak HP-LT event $\left(\mathrm{M}_{1}\right)$. Detailed structural mapping (Philippon et al. 2009) relates the deformation $\mathrm{D}_{1}$ to a topto-the-South sense of shear during subduction, best preserved in the mafic blueschists from the eastern part of the island. The second phase of deformation $\left(\mathrm{D}_{2}\right)$ coincides with the retrograde greenschist facies metamorphism and corresponds to the deformation of $\mathrm{S}_{1}$, and the formation of the crenulation cleavage $S_{2}$ and the large-scale antiform. According to Philippon et al. (2009), the deformation $\mathrm{D}_{2}$ is characterised by a top-to-the-North sense of shear, best shown by the metapelites, and associated with the exhumation of the blueschist facies rocks during the extensional reactivation of the subducted-related thrust zone.

Previous geochronological data

Previous studies targeted at dating the HP-LT metamorphic event related to the subduction process and the timing and duration of cooling related to the exhumation. Previous geochronological data using $\mathrm{K}-\mathrm{Ar}$ (glaucophane, phengite, barroisite) and ${ }^{40} \mathrm{Ar} /{ }^{39} \mathrm{Ar}$ (glaucophane) methods have given ages between $317 \pm 11 \mathrm{Ma}$ and $339 \pm 10 \mathrm{Ma}$ (Carpenter and Civetta 1976), and $320 \pm 6$ Ma (Maluski 1976), respectively. Later, the $\mathrm{Rb}-\mathrm{Sr}$ method allowed to obtain a micaschist whole-rock isochron age of $421 \pm 17 \mathrm{Ma}$ (Peucat and Cogné 1977; Peucat 1986), while Rb-Sr (Peucat 1986) and K-Ar ages (Hunziker, unpublished data; in Peucat 1986) of $342 \pm 11 \mathrm{Ma}$ to $396 \pm 18 \mathrm{Ma}$ and of $273 \pm 14 \mathrm{Ma}$ to $358 \pm 15 \mathrm{Ma}$, respectively, were obtained from whole-rock-phengite pairs. Detrital zircons from an albitic micaschist were also dated using the $\mathrm{U}-\mathrm{Pb}$ method and yielded an age of $399 \pm 62 \mathrm{Ma}$, interpreted as the maximum age for the HPLT event (Peucat 1986). Recently, the HP-LT event (blueschist facies) was dated at 358-365 Ma with the ${ }^{40} \mathrm{Ar} /{ }^{39} \mathrm{Ar}$ (phengite) and $\mathrm{Rb}-\mathrm{Sr}$ (whole rock, phengite and 
epidote) methods, while a younger age of 345-353 Ma was determined for the greenschist facies event related to the exhumation using the same methods (Bosse et al. 2005). These $\mathrm{Rb}-\mathrm{Sr}$ and $\mathrm{Ar}-\mathrm{Ar}$ data suggest a fast cooling rate.

\section{Analytical techniques}

Whole-rock geochemistry

Whole rock major element compositions of the samples were determined on fused lithium tetraborate $\left(\mathrm{Li}_{2} \mathrm{~B}_{4} \mathrm{O}_{7}\right)$ glass discs using a Philips PW2400 X-ray fluorescence spectrometer (XRF) at the Centre of Mineral Analysis at the University of Lausanne, Switzerland. Loss-on-ignition values were calculated based on the mass difference of a 2.5-3-g powdered rock aliquot before and after heating to $1,050^{\circ} \mathrm{C}$.

Trace element abundances were analysed on fragments from the same fused lithium tetraborate glass discs by laser ablation inductively coupled plasma mass-spectrometry (LA-ICP-MS) at the Institute of Mineralogy and Geochemistry, University of Lausanne. The LA-ICP-MS instrument consists of an ELAN 6100 DRC quadrupole ICPMS (Perkin Elmer, Canada) interfaced to a GeoLas 200 M 193 nm ArF excimer laser ablation system (Lambda Physik, Germany). The laser was operating at an on-sample energy density of about $10 \mathrm{~J} / \mathrm{cm}^{2}$, a $10-\mathrm{Hz}$ repetition rate and a $120-\mu \mathrm{m}$ pit size. Helium was used as a cell gas. The acquisition times for the background and the ablation interval corresponded to c. 70 and 30-35 s, respectively. Dwell times per isotope ranged from 10 to $20 \mathrm{~ms}$, and peak hopping mode was employed. The $\mathrm{ThO}^{+} / \mathrm{Th}^{+}$and $\mathrm{Ba}^{2+/} \mathrm{Ba}^{+}$ratios were optimised to c. 0.6 and $2.0-2.7 \%$, respectively. The National Institute of Standards and Technology standard reference material 612 was employed for external standardisation, using the average element abundances after Pearce et al. (1997). ${ }^{42} \mathrm{Ca}$ served as an internal standard. Intensity versus time data were reduced using LAMTRACE, a Lotus 1-2-3 spreadsheet written by Simon Jackson (Macquarie University, Australia). The detection limit is based on the $99 \%$ confidence level over the Gaussian counting statistics and is below $0.1 \mathrm{ppm}$ for most elements. The LA-ICP-MS data are generally accurate to within $0.5-10 \%$ on the basis of 3-4 replicate analyses.

The quality of the lithium tetraborate is often tested in the LA-ICP-MS laboratory. Blank lithium tetraborate glasses yield low $\mathrm{Pb}$, REE and HFSE contents $(<0.014 \mathrm{ppm})$. Typical background signals for the REE are significantly lower than $2 \mathrm{cps}$, the highest of the ablation peak signals amounting to $15.6 \mathrm{cps}$ for $\mathrm{Pb}(0.014 \mathrm{ppm})$ and $56.4 \mathrm{cps}$ for $\mathrm{Ce}(0.011 \mathrm{ppm})$. For comparison, the ablation peak signal during whole rock analyses amounts to 9,250 cps for $\mathrm{Pb}$ and
33,500 cps for Ce, corresponding to 23.9 and $38.9 \mathrm{ppm}$, respectively. Thus, the lithium tetraborate used for the preparation of lithium tetraborate glasses cannot affect the $\mathrm{Pb}$, REE and HFSE concentrations of the measured samples.

\section{Zircon dating}

Zircons were extracted from $\sim 1-\mathrm{kg}$ samples following the conventional procedures based on separation in diiodomethane $\left(\rho>3.32 \mathrm{~g} / \mathrm{cm}^{2}\right)$ and processing of the heavy concentrate on a Frantz magnetic separator (I > 1.33 A). Non-magnetic, euhedral and inclusion-free zircon grains between 30 and $100 \mu \mathrm{m}$ in length were handpicked and mounted in $0.5-\mathrm{cm}$-thick epoxy blocks. The grains were cut and polished to reveal core parts and internal surfaces. Prior to isotopic analyses, zircon mounts were imaged using a Jeol JSM-7001F scanning electron microscope (SEM) at the University of Geneva in the back-scattered electron (BSE) and cathodoluminescence (CL) mode under the operating conditions of $15 \mathrm{kV}$ of accelerating voltage and $15 \mathrm{nA}$ beam current.

$\mathrm{U}-\mathrm{Pb}$ dating of zircons was carried out on an Element XR sector field ICPMS (ThermoFisher Scientific, Germany and USA) interfaced to an UP193-FX ArF $193 \mathrm{~nm}$ excimer ablation system (New Wave Research, USA) at the Institute of Mineralogy and Geochemistry, University of Lausanne. Operating conditions of the laser included a $5-\mathrm{Hz}$ repetition rate, $25-35-\mu \mathrm{m}$ pit sizes and an on-sample energy density of c. $2.1 \mathrm{~J} / \mathrm{cm}^{2}$. Helium was used as a cell gas. The $\mathrm{ThO}^{+} / \mathrm{Th}^{+}$and $\mathrm{Ba}^{2+} / \mathrm{Ba}^{+}$ratios were optimised to 0.14 and $2.0-2.2 \%$, respectively. The $\mathrm{U}^{+} / \mathrm{Th}^{+}$intensity ratio for the SRM 612 standard was in the range of $110-115 \%$. The acquisition times for the background and the ablation interval amounted to c. $30 \mathrm{~s}$ each. A GJ-1 zircon standard was used for external standardisation (608.5 $\pm 0.4 \mathrm{Ma}$; Jackson et al. 2004). Typical acquisitions series consisted of four individual measurements of the GJ-1 standard, followed by nine measurements of the sample zircons, three measurements of the Harvard 91500 standard and four measurements of the GJ-1 standard. The average ${ }^{206} \mathrm{~Pb} /{ }^{238} \mathrm{U}$ age obtained for the Harvard 91500 standard is $1,068 \pm 12 \mathrm{Ma}$, which is similar to the TIMS value (1,065 Ma; Wiedenbeck et al. 1995). Intensity versus time data were reduced in LAMTRACE. The data were manually checked for the presence of intensity 'spikes' and corrected when necessary. No common lead correction was applied, a careful inspection of the cathodoluminescence images to avoid common lead rich domains, as well as a qualitative control of intensities acquired on masses 201 and 204 were used instead. Besides, Tera-Wasserburg diagrams (Tera and Wasserburg 1972) for all measurements were generated using Isoplot v. 3.41 (Ludwig 2003). 
Titanite dating

$\mathrm{U}-\mathrm{Pb}$ dating of titanite was performed in situ on $100-\mu \mathrm{m}-$ thick thin sections analysed using a Thermo-Finnigan Element XR sector field ICPMS (ThermoFisher Scientific, Germany and USA) coupled to a GeoLas Q + CompEx102193 nm ArF excimer laser ablation system (Lambda Physik, Germany) at the University of Montpellier. The laser was operated at a repetition rate of $4 \mathrm{~Hz}$ and beam diameter of $51 \mu \mathrm{m}$ with an energy density of c. $12 \mathrm{~J} / \mathrm{cm}^{2}$. Each analysis was preceded by a pre-ablation of the surface using a beam diameter of $77 \mu \mathrm{m}$. Helium was used as a cell gas. The $\mathrm{ThO}^{+} / \mathrm{Th}^{+}$was optimised to be $<1.0 \%$. Titanite from the Khan pegmatite (Namibia) served as standard, kindly provided by Larry Heaman (University of Alberta). Typical acquisitions series consisted of an alternation of two analyses of the Khan titanite standard (522.2 \pm $2.2 \mathrm{Ma}$; Heaman 2009) followed by five analyses of the sample titanites. Several analyses of a secondary standard from the Fish Canyon Tuff (28.395 $\pm 0.049 \mathrm{Ma}$; average ${ }^{207} \mathrm{~Pb} /{ }^{206} \mathrm{~Pb} \approx 0.04698 \pm 0.0012$; Schmitz and Bowring 2001), provided by the NERC Isotope Geosciences (British Geological Survey), were included in each series and yielded a ${ }^{207} \mathrm{~Pb} /{ }^{206} \mathrm{~Pb}$ ratio of $0.04661 \pm 0.0069$. The acquisition times for the background and the ablation interval amounted to about 15 and 45 s, respectively. Data were reduced using an Excel spreadsheet. Intervals of $30 \mathrm{~s}$ were selected in the signal and checked before the integration of time-resolved signals to avoid possible contamination by mineral inclusions. Common lead uncorrected ${ }^{206} \mathrm{~Pb} /{ }^{238} \mathrm{U}$ and ${ }^{207} \mathrm{~Pb} /{ }^{206} \mathrm{~Pb}$ ratios obtained for the Khan titanite standard during the course of this study are $0.0995 \pm 0005$ and $0.0615 \pm 0.0002 \quad(n=36)$, respectively. Both ratios are slightly higher than the TIMS values obtained by Heaman (2009) (c. $0.0827 \pm 0.0003$ and $0.0579 \pm 0.0009$ ), but their homogeneity and low standard deviation attest for the good precision of the results. As titanite is generally enriched in common $\mathrm{Pb}$, Tera-Wasserburg diagrams (Tera and Wasserburg 1972) were employed and generated by Isoplot version 3.41 (Ludwig 2003). Regression lines were anchored at a ${ }^{207} \mathrm{~Pb} /{ }^{206} \mathrm{~Pb}$ value given by the model of Stacey and Kramers (1975) or by radiogenic lead-free coeval minerals.

\section{Sample description}

\section{Albite gneiss GROA 115}

A layer of albite gneiss (GROA 115) has been recognised in the eastern part of the Ile de Groix, along the Plage des Sables Rouges (Figs. 2, 3). From the North to the South, this outcrop mainly consists of garnet-bearing micaschists with Mn nodules, micaschists with lenses of lawsonitebearing blueschists, garnet-bearing banded blueschists and garnet-bearing massive blueschists (Fig. 3b). Albite gneiss GROA 115 occurs as a 20-30-cm-thick layer within the micaschists (Figs. 3b, 4a). It displays one phase of deformation $\left(D_{1}\right)$ corresponding to the formation of the main foliation $S_{1}$. The rock foliation strike is oriented $\mathrm{NE}$ in the same direction as in the surrounding micaschists (Fig. 2), which gently dip to the SE (050N/15SE). The albite gneiss is a medium-grained well-foliated rock (Fig. 4b) composed of albite, quartz, K-feldspar (microcline), phengite, epidote rimming metamict allanite, garnet, biotite, titanite, zircon, ilmenite and occasional iron hydroxides (Fig. 4c-f). In the thin section, the gneissic texture is well developed, with the main foliation $S_{1}$ defined by the alignment of phengite and epidote. The magmatic origin is evidenced by the presence of pre-metamorphic porphyroclastic albite and microcline (up to $2 \mathrm{~mm}$ in size), and by the occurrence of metamict allanite inherited from the protolith in the core of metamorphic epidote, interpreted as magmatic allanite rimmed by epidote overgrowths during metamorphism. Titanite is also supposed to be of magmatic origin. Garnet is supposed to have grown during the HP-LT metamorphic event. Garnet grains are small $(<1 \mathrm{~mm})$ and display rare inclusions of epidote, quartz and iron oxides. Albite and microcline have recrystallised during metamorphism. Retrograde overprint manifests mainly in the almost complete replacement of biotite by chlorite. Finely dispersed iron hydroxides are common in the central part of the rock (GROA 115a) and are responsible for its reddish colour (Fig. 4b) and are rare in the white outer parts (GROA 115b).

Most zircon grains are colourless and transparent and display length-to-width ratios between 1:2 and 1:3.5, with size ranging from 20 to $100 \mu \mathrm{m}$. They are generally free of inclusions. Zircon crystals often reveal well developed to indistinct oscillatory growth zoning in back-scattered electron images (Fig. 7c, d). Most zircon grains belong to the P1-P5 type of Pupin (1980), which are generally described in alkaline magmas. Other grains correspond to the S2 and S10-15 types, generally found in calc-alkaline magmas.

Two hypotheses can be advanced to explain emplacement of the protolith: a microgranitic dyke or a volcanic tuff. A microgranitic dyke emplaced at subsurface is unlikely because of the low volume of orthogneiss and because the albite gneiss does not crosscut the lithological boundaries between the diverse rock types, which are present in the studied outcrop or at the scale of the island. The rock texture, as well as the field relationships with the micaschists, rather suggests that albite gneiss GROA 115 derives from a fine-grained volcanic tuff, interlayered with pelitic sediments. 
(a)
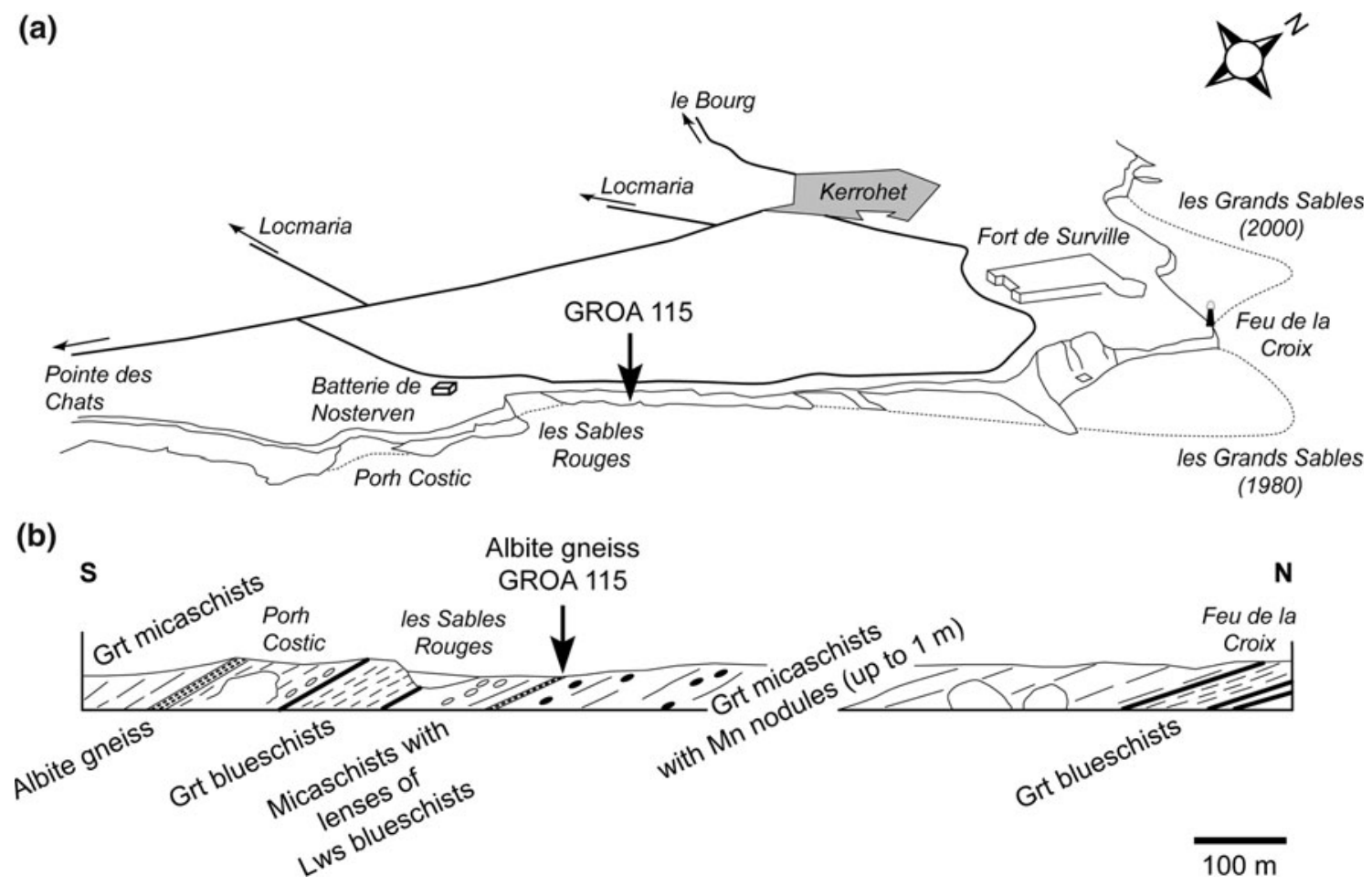

Fig. 3 Sketch map (a) and cross-section (b) of the eastern coast of the Ile de Groix and representing the structural relationships between the main lithologies and the locality of albite gneiss GROA 115 (Plage des Sables Rouges)

\section{Garnet-chloritoid-bearing micaschist GROA 102}

Well-foliated micaschist GROA 102 is a medium-grained rock cropping out in the western part of the island (Pen Men; Fig. 2). The two phases of deformation $\left(D_{1}\right.$ and $\left.D_{2}\right)$ usually described in the metamorphic rocks of the Ile de Groix are frequently observed in this sample. The blueschist facies assemblage, related to $D_{1}$, includes garnet, chloritoid, phengite, paragonite, titanite, quartz and apatite. Accessory rutile and tourmaline are sometimes present. Garnet porphyroblasts usually contain small inclusions of titanite, epidote and ilmenite. Titanite crystals are large (up to 500 microns), well shaped and oriented along the foliation. Its growth is supposed to have occurred close to peak-metamorphic P-T conditions and lasted up to the beginning of retrogression. Retrograde greenschist facies overprint, related to $D_{2}$, corresponds to the growth of chlorite, ilmenite and hematite. A second generation of phengite, post-kinematic to $D_{1}$, is sometimes present.

\section{Whole-rock geochemistry}

\section{Albite gneiss GROA 115}

Samples GROA $115 \mathrm{a}$ and $\mathrm{b}$ are characterised by very high contents of $\mathrm{SiO}_{2}$ and high contents of $\mathrm{Al}_{2} \mathrm{O}_{3}$
(75.2-75.5 and $13.9 \mathrm{wt} \%$, respectively; see Table 1). $\mathrm{MgO}, \mathrm{Fe}_{2} \mathrm{O}_{3}, \mathrm{TiO}_{2}$ as well as LOI values are low (Table 1). $\mathrm{K}_{2} \mathrm{O}$ (2.3-2.4 wt\%) and $\mathrm{Na}_{2} \mathrm{O}$ (2.2 wt\%) contents are higher than $\mathrm{CaO}$ content (1.6-1.9 wt\%). The samples display $\mathrm{A} / \mathrm{CNK}$ and $\mathrm{A} / \mathrm{NK}$ ratios of $1.47-1.53$ and 2.27-2.29, respectively. The $\mathrm{Fe}-\mathrm{no}[\mathrm{FeOt} /(\mathrm{FeOt}+$ $\mathrm{MgO})]$ is high and corresponds to $0.78-0.81$. Because of high $\mathrm{SiO}_{2}$ and $\mathrm{Al}_{2} \mathrm{O}_{3}$ contents, the protolith of albite gneiss GROA 115 corresponds to a peraluminous leucogranite (Frost et al. 2001), provided that its composition has not been modified during metamorphism. The major element composition of albite gneiss GROA 115 is generally close to that of A-type anorogenic granites (Finnish rapakivi granite [wiborgite] and Spirit Mountain pluton [Newberry Mountains]; Haapala et al. 2005) and S-type granites (Lachlan granodiorite, Maas et al. 1997; Velay leucogranite, Williamson et al. 1997) (Table 2), which display high $\mathrm{SiO}_{2}$ and $\mathrm{Al}_{2} \mathrm{O}_{3}$ contents and low $\mathrm{Fe}_{2} \mathrm{O}_{3}, \mathrm{CaO}$ and $\mathrm{MgO}$ contents. It is also similar to the composition of the high-silica Ikaria I-type granite (Altherr and Siebel 2002), emplaced in a back-arc setting (Table 2). However, albite gneiss GROA 115 shows lower $\mathrm{K}_{2} \mathrm{O}$ and $\mathrm{Na}_{2} \mathrm{O}$ contents compared with the various granites. The major element composition of albite gneiss GROA 115 is also enriched in $\mathrm{Fe}_{2} \mathrm{O}_{3}, \mathrm{CaO}$ and $\mathrm{MgO}$ compared to the Saint-Malo anatectic granite (Milord et al. 2001) (Table 2). 

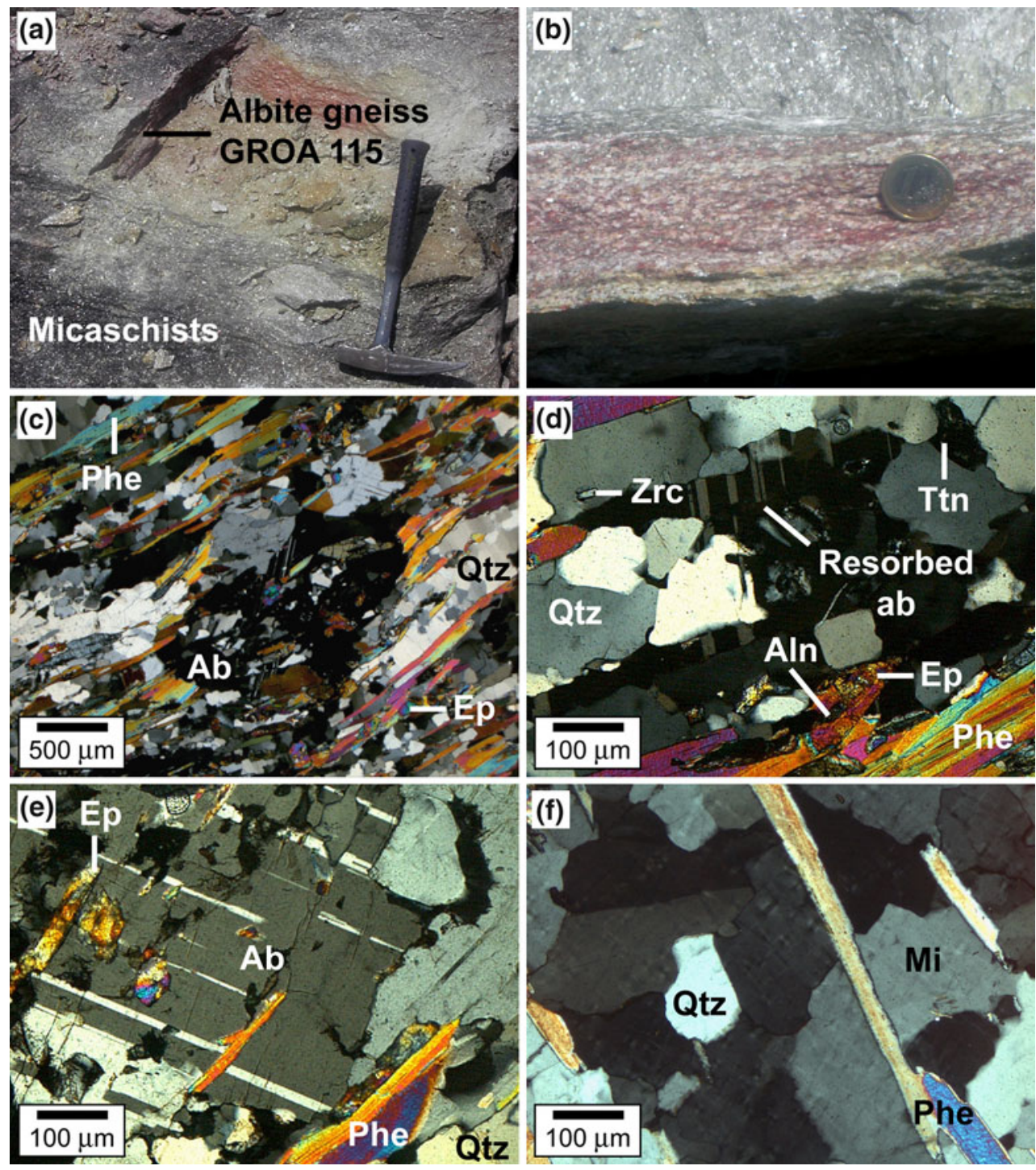

Fig. 4 Photomicrographs of albite gneiss GROA 115. a The albite gneiss crops out as a $40-\mathrm{cm}$-thick level within micaschists. b Typical macroscopic aspect of albite gneiss GROA 115. The red colour is due to the presence of scattered iron hydroxides. c Typical assemblage and gneissic texture evidenced by the alignment of phengite and

In the CI Chondrite-normalised multi-element and REE diagrams (Fig. 5a, b), albite gneiss GROA 115 (a, b) is characterised by negative $\mathrm{Nb}$, $\mathrm{Ti} \mathrm{Sr}$ and $\mathrm{Eu}$ anomalies and positive $\mathrm{Th}, \mathrm{Zr}$ and $\mathrm{Hf}$ anomalies. A weak positive $\mathrm{Ce}$ anomaly is also present. LREE are moderately enriched over HREE $\left[(\mathrm{Ce} / \mathrm{Yb})_{\mathrm{N}} \sim 2.0-2.4\right] . \mathrm{LREE}_{\mathrm{N}}$ do not exceed 64. MREE are slightly depleted compared to LREE and HREE. MREE and HREE abundances are close to MORB.

Albite gneiss GROA 115 generally plots between the A-type anorogenic and the S-type granite patterns. The LILE and LREE contents in albite gneiss GROA 115 are similar to those of the S-type Velay leucogranite (Williamson et al. 1997). The LREE, $\mathrm{Nb}, \mathrm{Zr}$ and $\mathrm{Hf}$

quartz layers. d Albite porphyroclast partly resorbed by quartz. Allanite is present in epidote core. e Albite porphyroclast with polysynthetic and Carlsbad twinning. f Microcline porphyroclast. The mineral abbreviations are from Kretz (1983)

contents in albite gneiss GROA 115 are generally lower those in A-type granites and Lachlan S-type granodiorite (Maas et al. 1997), but the relative distribution pattern of $\mathrm{Rb}, \mathrm{Ba}, \mathrm{Th}, \mathrm{Nb}, \mathrm{MREE}$ and HREE in albite gneiss GROA 115 (Fig. 5a, b) is similar to that of Wiborgite rapakivi and A-type Spirit Mountain granites (Haapala et al. 2005). The trace element pattern of albite gneiss GROA 115 is similar to the Ikaria I-type granite (Altherr and Siebel 2002), even if albite gneiss GROA 115 is enriched in HREE and depleted in $\mathrm{U}$. The $\mathrm{Ta} / \mathrm{Yb}$ and $\mathrm{Th} / \mathrm{Yb}$ ratios are consistent with magmas from volcanic arcs or having undergone a crustal contamination (Pearce 1983) (Table 1). In the $\mathrm{Y}+\mathrm{Nb}$ versus $\mathrm{Rb}$ diagram (Pearce et al. 1984), the rocks 
Table 1 Major and trace element compositions of the studied rock

\begin{tabular}{|c|c|c|c|}
\hline & $\begin{array}{l}\text { GROA } 115 a \\
\text { Albite gneiss }\end{array}$ & $\begin{array}{l}\text { GROA } 115 b \\
\text { Albite gneiss }\end{array}$ & $\begin{array}{l}\text { GROA } 102 \\
\text { Micaschist }\end{array}$ \\
\hline $\mathrm{SiO}_{2}$ & 75.18 & 75.52 & 48.42 \\
\hline $\mathrm{TiO}_{2}$ & 0.22 & 0.23 & 1.22 \\
\hline $\mathrm{Al}_{2} \mathrm{O}_{3}$ & 13.93 & 13.93 & 26.17 \\
\hline $\mathrm{Fe}_{2} \mathrm{O}_{3}$ & 2.29 & 2.21 & 9.76 \\
\hline $\mathrm{MnO}$ & 0.04 & 0.03 & 0.46 \\
\hline $\mathrm{MgO}$ & 0.48 & 0.55 & 2.66 \\
\hline $\mathrm{CaO}$ & 1.86 & 1.63 & 1.03 \\
\hline $\mathrm{Na}_{2} \mathrm{O}$ & 2.21 & 2.16 & 0.22 \\
\hline $\mathrm{K}_{2} \mathrm{O}$ & 2.26 & 2.40 & 5.97 \\
\hline $\mathrm{P}_{2} \mathrm{O}_{5}$ & 0.04 & 0.04 & 0.21 \\
\hline LOI & 1.45 & 1.52 & 4.12 \\
\hline $\mathrm{Cr}_{2} \mathrm{O}_{3}$ & n.d. & n.d. & 0.02 \\
\hline $\mathrm{NiO}$ & n.d. & n.d. & 0.01 \\
\hline Total & 99.96 & 100.22 & 100.26 \\
\hline $\mathrm{FeOt}$ & 2.06 & 1.99 & 8.78 \\
\hline $\mathrm{Mg \#}$ & 29.50 & 32.92 & 35.05 \\
\hline $\mathrm{Be}$ & $2.9(0.4)$ & $2.9(0.4)$ & $4.1(0.7)$ \\
\hline $\mathrm{Sc}$ & $12(0.2)$ & $11.5(0.4)$ & $26.1(0.5)$ \\
\hline $\mathrm{V}$ & $28.6(0.6)$ & $28.5(0.3)$ & $192(8)$ \\
\hline $\mathrm{Cr}$ & $158.3(0.2)$ & $114(12)$ & $256(13)$ \\
\hline $\mathrm{Co}$ & $36(2)$ & $39(1)$ & $24(1)$ \\
\hline $\mathrm{Ni}$ & $5.8(0.3)$ & $5.7(0.9)$ & $54(2)$ \\
\hline $\mathrm{Cu}$ & $8.8(0.8)$ & $8.3(0.5)$ & $44(2)$ \\
\hline $\mathrm{Zn}$ & $31(2)$ & $29(3)$ & $86(3)$ \\
\hline $\mathrm{Ga}$ & $31.3(0.5)$ & $30(2)$ & $95(5)$ \\
\hline $\mathrm{Rb}$ & 89 (2) & $92.5(0.7)$ & $194(8)$ \\
\hline $\mathrm{Sr}$ & $201(2)$ & $181(2)$ & $43.2(0.8)$ \\
\hline $\mathrm{Y}$ & $33.4(0.5)$ & $28.2(0.4)$ & $26.8(0.5)$ \\
\hline $\mathrm{Zr}$ & 139 (3) & $127(1)$ & 157 (4) \\
\hline $\mathrm{Nb}$ & $7.6(0.2)$ & $7.6(0.1)$ & $23.7(0.5)$ \\
\hline Cs & $5.0(0.2)$ & $4.7(0.2)$ & $9.5(0.5)$ \\
\hline $\mathrm{Ba}$ & 298 (6) & $319(7)$ & 818 (15) \\
\hline $\mathrm{La}$ & $15.3(0.3)$ & $9.5(0.3)$ & $47(2)$ \\
\hline $\mathrm{Ce}$ & $38.9(0.7)$ & $29(1)$ & $105(3)$ \\
\hline $\operatorname{Pr}$ & $4.1(0.2)$ & $2.70(0.05)$ & $10.6(0.3)$ \\
\hline $\mathrm{Nd}$ & $15.3(0.8)$ & $11.3(0.2)$ & $40(2)$ \\
\hline $\mathrm{Sm}$ & $3.6(0.4)$ & $2.6(0.2)$ & $7.3(0.2)$ \\
\hline $\mathrm{Eu}$ & $0.43(0.07)$ & $0.31(0.03)$ & $1.5(0.1)$ \\
\hline $\mathrm{Gd}$ & $4.0(0.3)$ & $3.49(0.09)$ & $5.7(0.5)$ \\
\hline $\mathrm{Tb}$ & $0.78(0.04)$ & $0.58(0.04)$ & $0.87(0.01)$ \\
\hline Dy & $5.5(0.08)$ & $4.6(0.2)$ & $5.2(0.3)$ \\
\hline Но & $1.2(0.1)$ & $1.08(0.08)$ & $1.03(0.04)$ \\
\hline $\mathrm{Er}$ & $3.8(0.1)$ & $3.43(0.05)$ & $3.1(0.2)$ \\
\hline $\mathrm{Tm}$ & $0.66(0.02)$ & $0.52(0.04)$ & $0.49(0.04)$ \\
\hline $\mathrm{Yb}$ & $4.6(0.3)$ & $3.95(0.01)$ & $3.2(0.1)$ \\
\hline $\mathrm{Lu}$ & $0.67(0.01)$ & $0.61(0.09)$ & $0.47(0.03)$ \\
\hline $\mathrm{Hf}$ & $4.7(0.1)$ & $4.5(0.3)$ & $4.5(0.1)$ \\
\hline $\mathrm{Ta}$ & $1.41(0.03)$ & $1.49(0.02)$ & $2.0(0.1)$ \\
\hline
\end{tabular}

Table 1 continued

\begin{tabular}{llll}
\hline & $\begin{array}{l}\text { GROA 115a } \\
\text { Albite gneiss }\end{array}$ & $\begin{array}{l}\text { GROA 115b } \\
\text { Albite gneiss }\end{array}$ & $\begin{array}{l}\text { GROA 102 } \\
\text { Micaschist }\end{array}$ \\
\hline $\mathrm{Pb}$ & $23.9(0.2)$ & $23.0(0.7)$ & $6.9(0.2)$ \\
$\mathrm{Th}$ & $16.7(0.2)$ & $16.5(0.4)$ & $21.3(0.8)$ \\
$\mathrm{U}$ & $1.22(0.02)$ & $1.30(0.09)$ & $1.97(0.08)$ \\
$(\mathrm{Ce} / \mathrm{Yb})_{\mathrm{N}}(\mathrm{PM})^{*}$ & 2.37 & 3.82 & 9.11 \\
$\mathrm{Ta} / \mathrm{Yb}$ & 0.31 & 0.38 & \\
$\mathrm{Th} / \mathrm{Yb}$ & 3.67 & 4.16 & \\
\hline
\end{tabular}

Oxides in wt $\%$; trace elements in $\mu \mathrm{g} / \mathrm{g}$

Total $\mathrm{Fe}$ is reported as $\mathrm{Fe}_{2} \mathrm{O}_{3} ; \mathrm{Mg} \#=100 \times \mathrm{Mg} /\left[\mathrm{Mg}+\mathrm{Fe}^{2+}\right] ;$ LOI loss on ignition

$1 \sigma$ standard deviations $(n=3-4)$ for trace elements are given in parentheses

* $(\mathrm{Ce} / \mathrm{Yb})_{\mathrm{N}}(\mathrm{PM})$ normalised to the Primitive Mantle (normalisation values are from Sun and McDonough, 1989)

plot within the field of volcanic arc granites, close to the limit with the field of within-plate anorogenic granites (Fig. 6a). In the Rb-Hf-Ta triangular plot of Harris et al. (1986), the rocks plot on the divide of late and post-collisional granite, volcanic arc granites and within-plate anorogenic granites (Fig. 6b).

\section{Micaschist GROA 102}

Micaschist GROA 102 is strongly enriched in $\mathrm{Al}_{2} \mathrm{O}_{3}$ (26.2\%) and displays high $\mathrm{K}_{2} \mathrm{O}$ and $\mathrm{FeO}$ contents, and low $\mathrm{SiO}_{2}(48.4 \%), \mathrm{MgO}, \mathrm{Na}_{2} \mathrm{O}$, and $\mathrm{CaO}$ contents (Table 1).

The CI Chondrite-normalised multi-element and REE patterns of micaschist GROA 102 show a strong fractionation of LILE and LREE over HFSE and HREE [ $(\mathrm{Ce} /$ $\mathrm{Yb})_{\mathrm{N}} \sim$ 9.1] (Fig. 5c, d) and display negative $\mathrm{Nb}, \mathrm{Pb}, \mathrm{Sr}$ and $\mathrm{Ti}$ anomalies and positive $\mathrm{Ba}$ and $\mathrm{Th}$ anomalies. Micaschist GROA 102 is a metasediment derived from continental sediments, whose composition is similar to the GLOSS, containing $76 \%$ of terrigeneous material (Global Ocean Subducting Sediment; Plank and Langmuir 1998). However, its major element chemistry suggests that the sediment may have incorporated a basic volcanoclastic component.

\section{U-Pb geochronology}

Geochronology of albite gneiss GROA 115

Zircons

A total of one hundred and fifty zircons were extracted from samples GROA 115a and b. Fifty-four representative 
Table 2 Major element composition for average albite gneiss GROA 115, compared with different A-type, S-type and I-type granitoids

\begin{tabular}{|c|c|c|c|c|c|c|c|}
\hline & $\begin{array}{l}\text { Orthogneiss } \\
\text { GROA } 115 \\
\text { (average) }\end{array}$ & $\begin{array}{l}\text { Finnish rapakivi } \\
\text { granite Wiborgite }\end{array}$ & $\begin{array}{l}\text { Spirit Mountain } \\
\text { granite A-type }\end{array}$ & $\begin{array}{l}\text { Lachlan } \\
\text { granodiorite } \\
\text { S-type granite }\end{array}$ & $\begin{array}{l}\text { Velay } \\
\text { leucogranite } \\
\text { S-type granite }\end{array}$ & $\begin{array}{l}\text { Saint-Malo } \\
\text { anatectic } \\
\text { granite }\end{array}$ & $\begin{array}{l}\text { Ikaria granite } \\
\text { I-type granite }\end{array}$ \\
\hline $\mathrm{SiO}_{2}$ & 75.35 & 69.96 & 73.20 & 69.27 & 74.39 & 74.30 & 74.70 \\
\hline $\mathrm{TiO}_{2}$ & 0.22 & 0.42 & 0.29 & 0.62 & 0.18 & 0.07 & 0.20 \\
\hline $\mathrm{Al}_{2} \mathrm{O}_{3}$ & 13.93 & 13.41 & 14.00 & 14.87 & 14.86 & 15.07 & 13.70 \\
\hline $\mathrm{Fe}_{2} \mathrm{O}_{3}$ & 2.25 & 4.17 & 1.84 & 4.64 & 1.07 & 0.46 & 1.35 \\
\hline $\mathrm{MnO}$ & 0.03 & 0.06 & 0.05 & 0.11 & 0.04 & 0.01 & 0.02 \\
\hline $\mathrm{MgO}$ & 0.51 & 0.35 & 0.51 & 2.05 & 0.32 & 0.11 & 0.40 \\
\hline $\mathrm{CaO}$ & 1.74 & 2.16 & 1.08 & 2.20 & 1.14 & 0.84 & 1.64 \\
\hline $\mathrm{Na}_{2} \mathrm{O}$ & 2.18 & 3.09 & 3.98 & 2.12 & 3.35 & 3.51 & 3.42 \\
\hline $\mathrm{K}_{2} \mathrm{O}$ & 2.33 & 5.46 & 4.87 & 4.11 & 4.90 & 4.19 & 4.39 \\
\hline $\mathrm{P}_{2} \mathrm{O}_{5}$ & 0.04 & 0.11 & 0.06 & - & 0.17 & 0.26 & 0.05 \\
\hline LOI $\left(\mathrm{H}_{2} \mathrm{O}\right)$ & 1.49 & 0.31 & 0.40 & - & - & 0.97 & 0.26 \\
\hline Total & 100.09 & 99.50 & 100.28 & 99.99 & 100.41 & 99.79 & 100.13 \\
\hline
\end{tabular}

Analyses of the Finnish rapakivi and the Spirit Mountain granites from Haapala et al. (2005); analyses of the Lachlan granodiorite from Maas et al. (1997); analyses of the Velay leucogranite from Williamson et al. (1997); analyses of the Saint-Malo anatectic granite from Milord et al. (2001); and analyses of the Ikaria granite from Altherr and Siebel (2002)
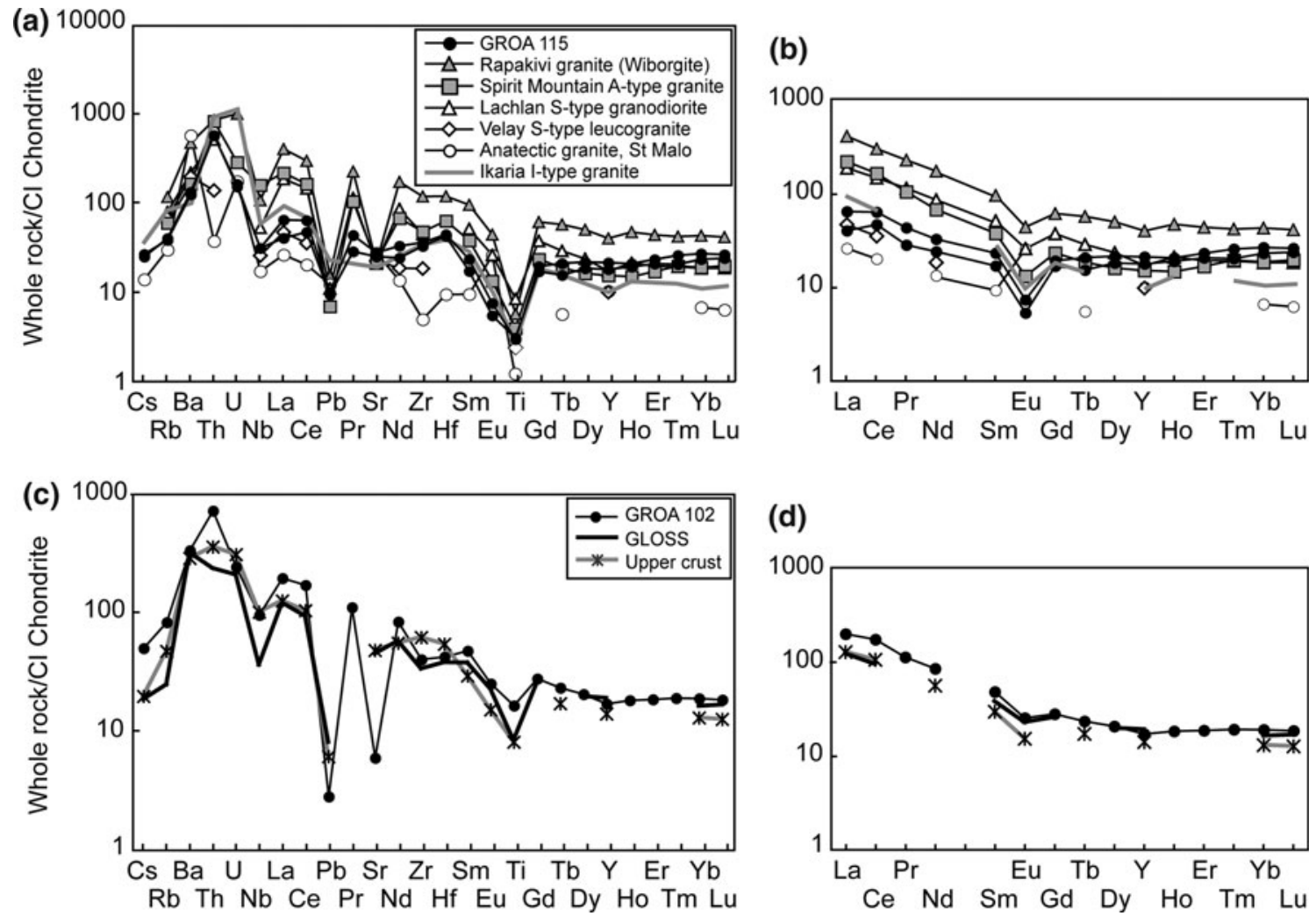

Fig. 5 CI Chondrite-normalised multi-element diagrams illustrating the whole-rock trace element compositions of albite gneiss GROA 115 (a, b) and micaschist GROA 102 (c, d) in comparison with Finnish rapakivi granite (wiborgite) and Spirit Mountain pluton (Newberry Mountains) (Haapala et al. 2005), Lachlan granodiorite
(Maas et al. 1997), Velay leucogranite (Williamson et al. 1997), St-Malo anatectic granite (Milord et al. 2001), Ikaria granite (Altherr and Siebel 2002), Upper Crust (Taylor and McLennan 1981) and GLOSS (Plank and Langmuir 1998). Normalisation values are from Sun and McDonough (1989) 


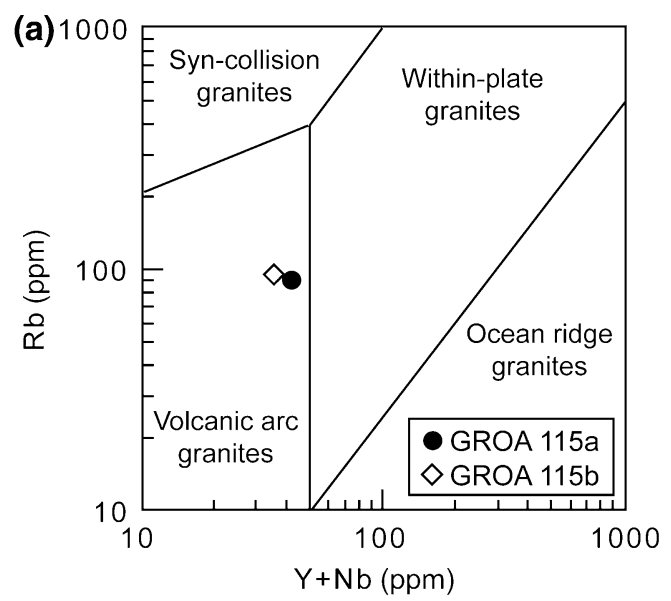

(b)

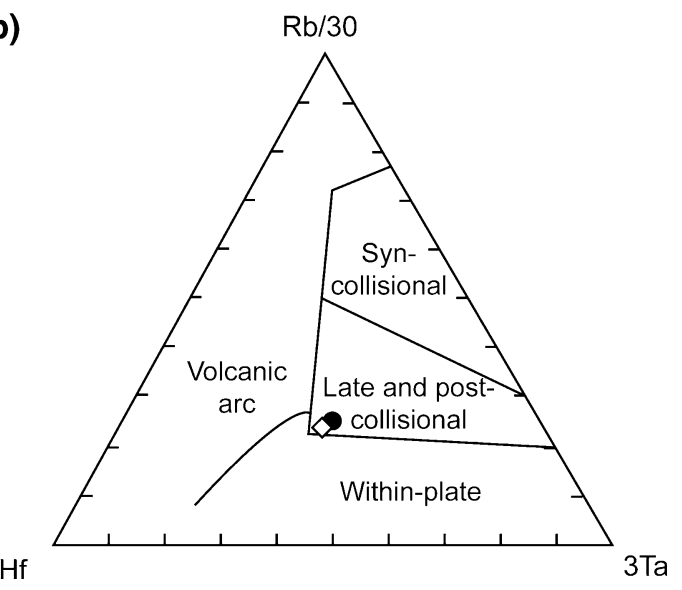

Fig. 6 Tectonic discrimination diagrams a from Pearce et al. (1984) and $\mathbf{b}$ from Harris et al. (1986), for albite gneiss GROA 115

grains were dated using the $\mathrm{U}-\mathrm{Pb}$ method. Two-point measurements were carried out on large grains, in order to distinguish core and rim parts. No common lead correction was applied. The difference between the amounts of ${ }^{204} \mathrm{~Pb}$ measured in the background and in the individual laser ablation runs corresponded to $0-40 \mathrm{cps}$, indicating negligible common lead contents. The ${ }^{206} \mathrm{~Pb} /{ }^{204} \mathrm{~Pb}$ ratio is generally higher than 1,400 and can increase up to 30,000 .

The distribution of the ${ }^{206} \mathrm{~Pb} /{ }^{238} \mathrm{U}$ ages obtained for zircons of P1-P5 type in samples GROA 115a and b is similar and mainly corresponds to the Early Ordovician $(465.7-512.4 \mathrm{Ma} ; n$ (grains) $=42$; Fig. 7a-c). Younger ages of about 460-470 Ma are interpreted to result from a radiogenic lead loss, during the HP-LT metamorphism. Morphologically different zircon grains of S2 and S10-15 type yield late Neoproterozoic ${ }^{206} \mathrm{~Pb} /{ }^{238} \mathrm{U}$ ages [546.6647.4 Ma; $n$ (grains) $=7$; Fig. 7b, d], while five grains give older ages, extending to 2,855.4 Ma (Fig. 7a). The weighted average of Ordovician zircons yields an average age of $481.1 \pm 3.7 \mathrm{Ma}$ [MSWD $=0.30(2 \sigma) ; n$ (grains $)=$ 42]. The $\mathrm{U}-\mathrm{Pb}$ isotope data (Table 3 ) were plotted in a
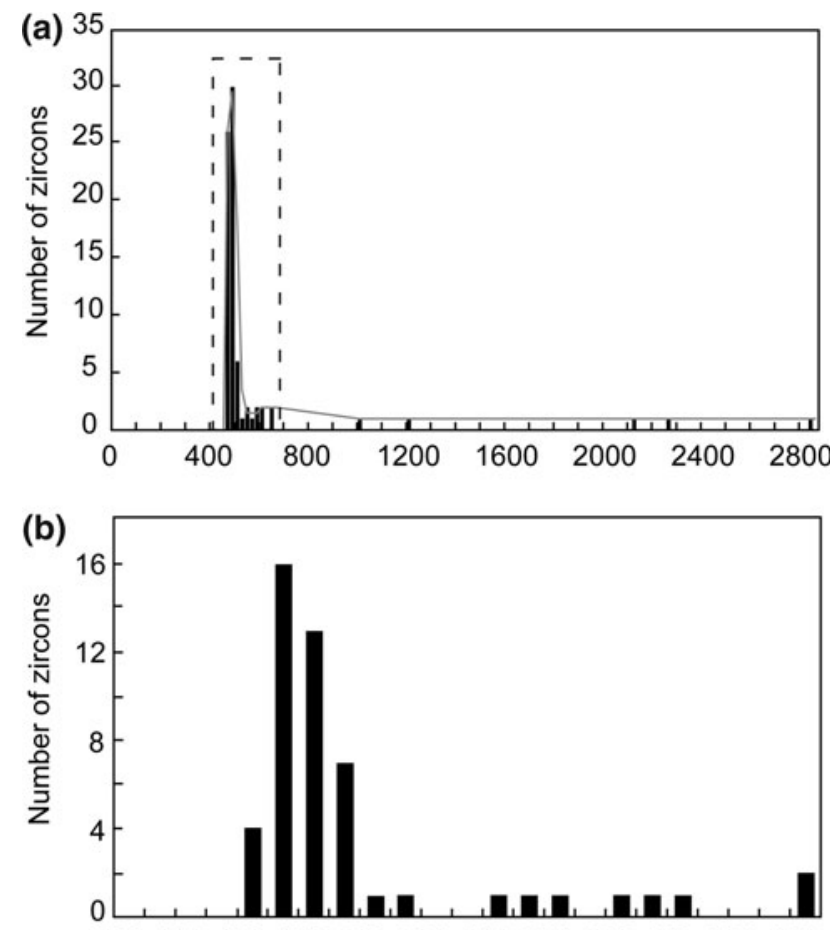

420440460480500520540560580600620640

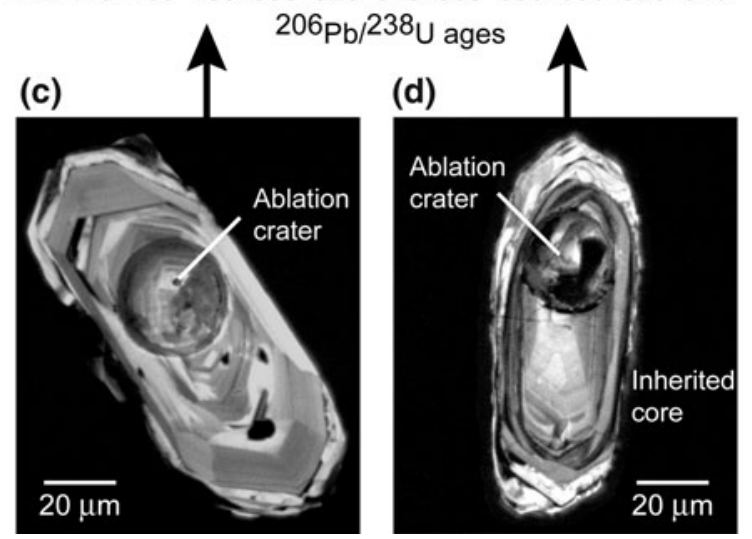

Fig. 7 Zircon ${ }^{206} \mathrm{~Pb} /{ }^{238} \mathrm{U}$ age histograms and $\mathrm{CL}$ images for albite gneiss GROA 115. a All data. The distribution of ages indicates that most zircons plot between 460 and $640 \mathrm{Ma}$. b Blow-up of the Cambro-Ordovician and Neoproterozoic ages. Zircons with CambroOrdovician ages (c) represent the age of the felsic magmatic emplacement, while zircons with Neoproterozoic ages (d) are inherited from the Cadomian basement

Tera-Wasserburg diagram (Fig. 8b). They yield a lower intercept age of $481.8 \pm 4.9(2 \sigma)$ Ma with a MSWD of 4.7 .

\section{Titanite}

Titanite from albite gneiss GROA 115 was analysed on two thin sections $(n=15)$ (Table 4$)$. It appears as anhedral crystals ranging in size from 40 to $200 \mu \mathrm{m}$. LA-ICP-MS analyses of titanite revealed high amounts of common lead. In albite gneiss GROA 115, common lead was corrected 


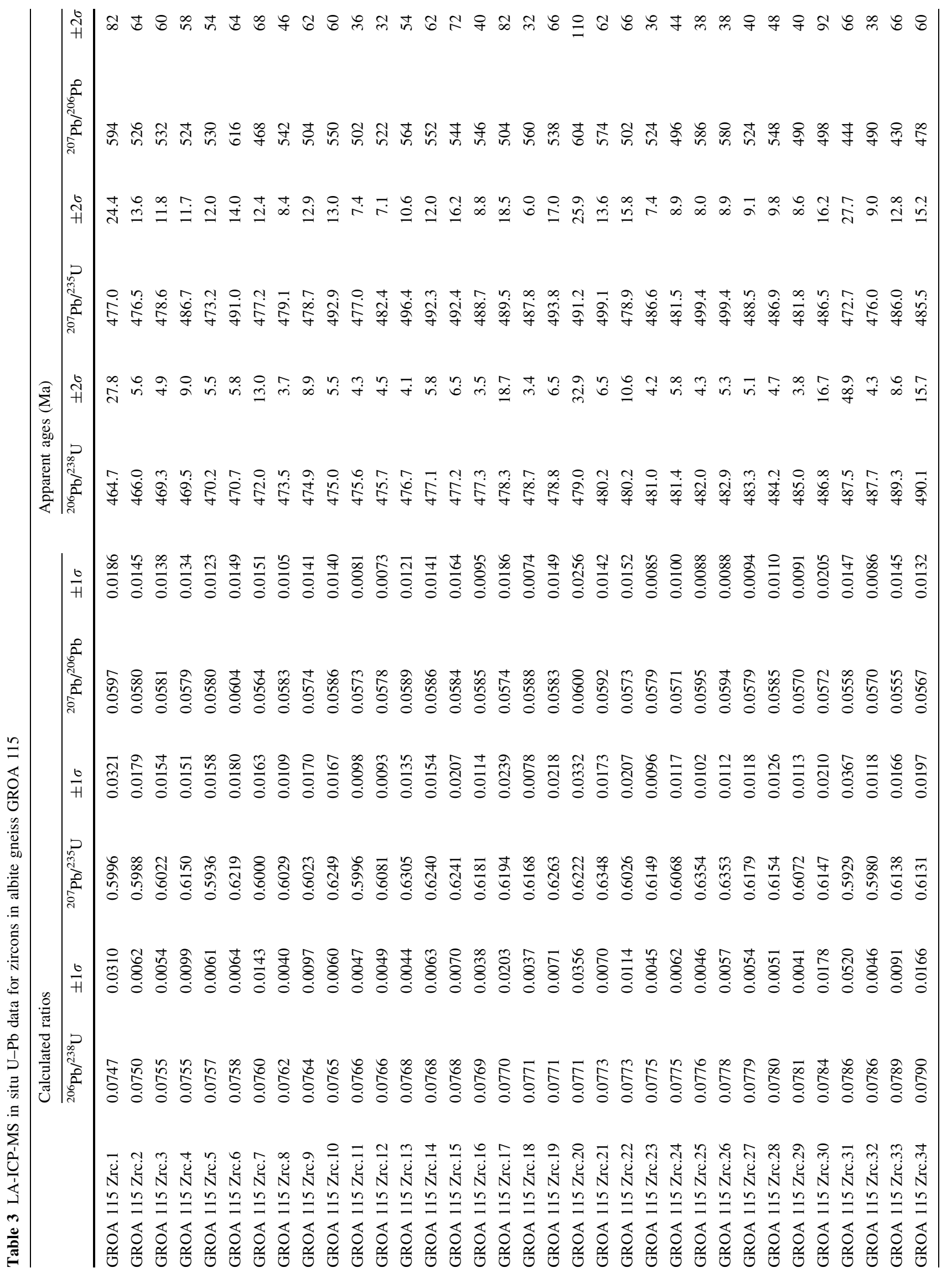




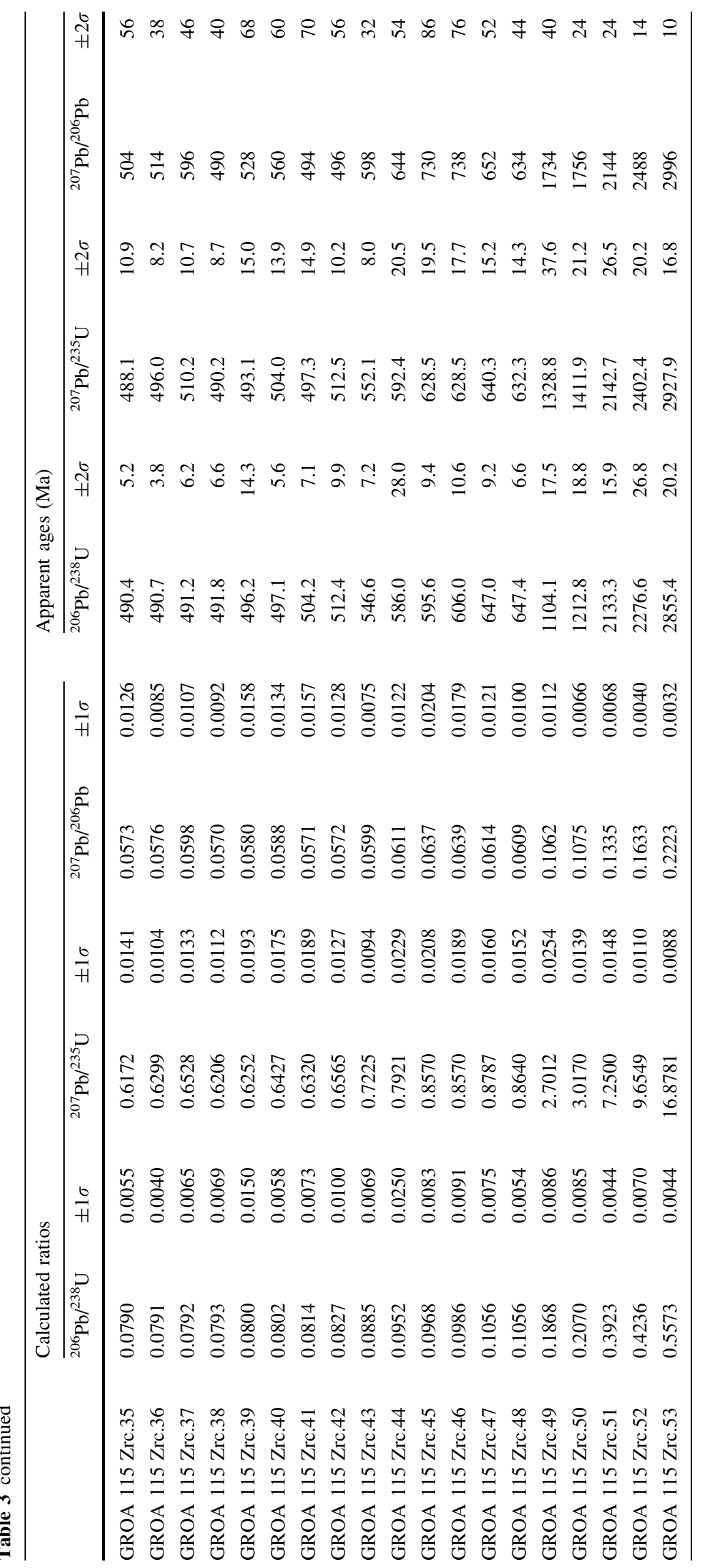


Fig. $8 \mathrm{U}-\mathrm{Pb}$ zircon and titanite data in albite gneiss GROA 115. a ${ }^{206} \mathrm{~Pb} /{ }^{238} \mathrm{U}$ ages of LA-ICPMS Ordovician zircon $\mathrm{U}-\mathrm{Pb}$ data plotted as weighted average. b Tera-Wasserburg plot of LA-ICP-MS Ordovician zircon $\mathrm{U}-\mathrm{Pb}$ data. c TeraWasserburg plot of $\mathrm{Pb}$ corrected LA-ICP-MS data for titanite. d Tera-Wasserburg plot for Ordovician zircon and titanite. Age calculated at $95 \%$ level of confidence
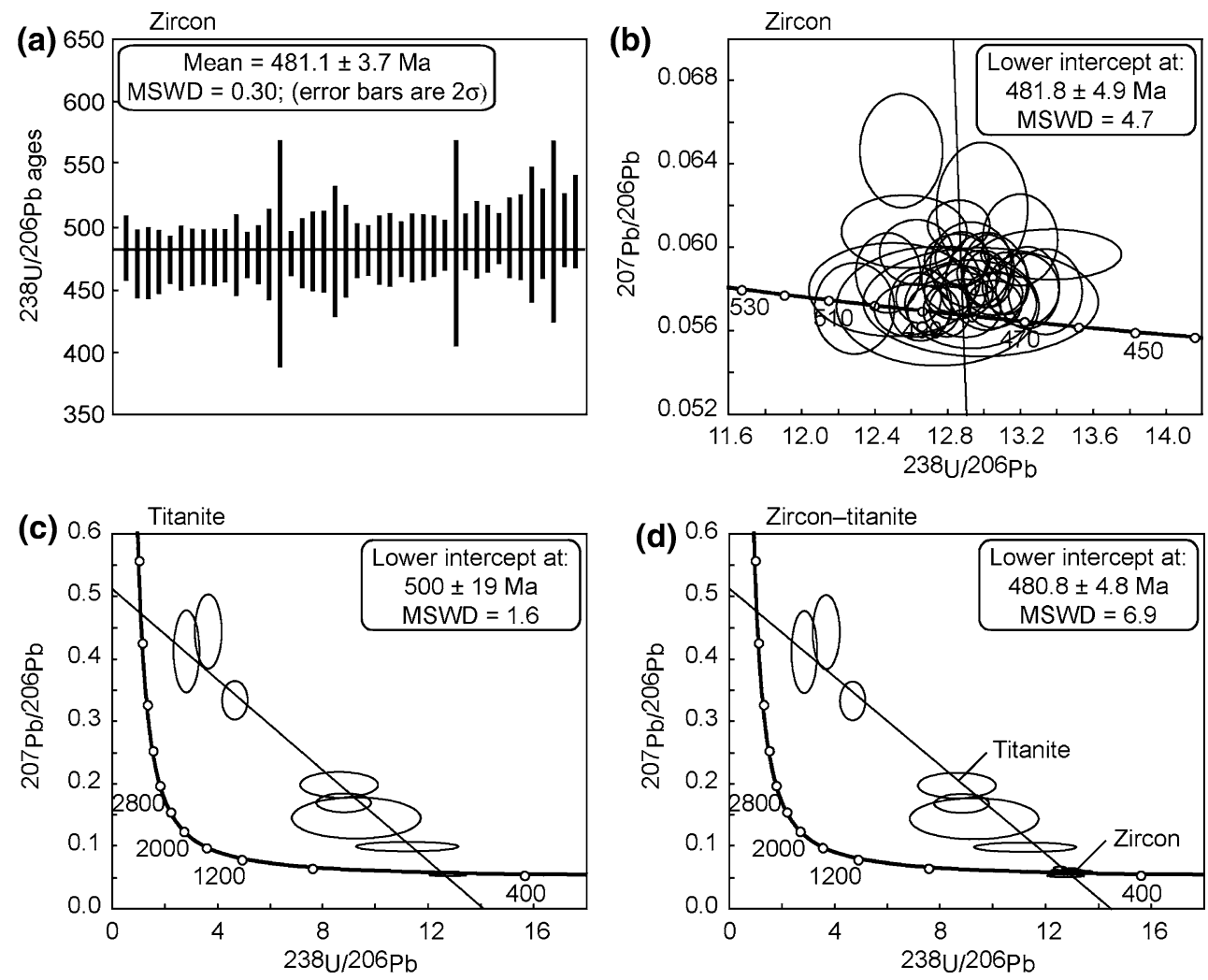

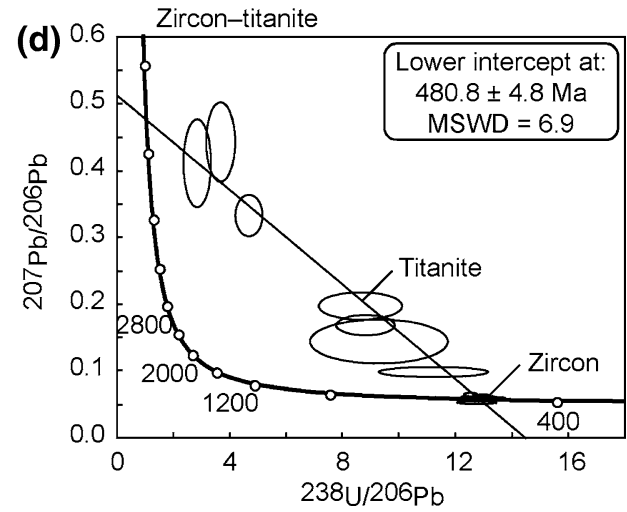

using the "204 method" based on measurement of the nonradiogenic ${ }^{204} \mathrm{~Pb}$ isotope. The model ${ }^{206} \mathrm{~Pb} /{ }^{204} \mathrm{~Pb}$ ratio (Stacey and Kramers 1975) was employed, while the ${ }^{207} \mathrm{~Pb} /{ }^{206} \mathrm{~Pb}$ initial ratio was measured in a coeval albite. A value of $0.858 \pm 0.016$ (at $2 \sigma$ ) was determined, and plots within error of the value of 0.865 were given by the model terrestial lead composition of Stacey and Kramers (1975). Analyses with very low radiogenic $\mathrm{Pb}$ were ignored. The data were plotted in a Tera-Wasserburg diagram and yield a lower intercept age of $500 \pm 19 \mathrm{Ma}(2 \sigma)$, with a MSWD of 1.6 (Fig. 8c). In addition, titanite and zircon U-Pb data were represented together in a Tera-Wasserburg diagram, which defines an average of ${ }^{206} \mathrm{~Pb} /{ }^{238} \mathrm{U}$ ages at $480.8 \pm$ 4.8 Ma $(2 \sigma)$, with a MSWD of 6.9.

Titanite geochronology of micaschist GROA 102

Titanite in micaschist GROA 102 consists of large euhedral to subhedral crystals, ranging in size from 40 to $200 \mu \mathrm{m}$. Forty-five analyses of titanite were performed on two thin sections (Table 5). Titanite displays high amounts of common lead, as observed for titanite in albite gneiss GROA 115. Uncorrected data were plotted in a TeraWasserburg diagram and yield a late Devonian lower intercept age of $376 \pm 36 \mathrm{Ma}(2 \sigma)$, with a MSWD of 2.5 (Fig. 9a). Besides, common lead was corrected using the "204 method". The ${ }^{206} \mathrm{~Pb} /{ }^{204} \mathrm{~Pb}$ and ${ }^{207} \mathrm{~Pb} /{ }^{206} \mathrm{~Pb}$ initial ratios were taken from a titanite analysis without radiogenic lead and with very low $\mathrm{U}$ and $\mathrm{Th}$ contents $(<0.5 \mathrm{ppm})$ and correspond to 16.88 and $0.8403 \pm 0.1862$ (at $2 \sigma$ ), respectively. Analyses with very low radiogenic $\mathrm{Pb}$ were ignored. The corrected data yield a late Devonian lower intercept age of $366 \pm 33 \mathrm{Ma}(2 \sigma)$, with a MSWD of 0.44 (Fig. 9b).

\section{Discussion}

Significance of the U-Pb ages

The zircon and titanite $\mathrm{U}-\mathrm{Pb}$ ages obtained in albite gneiss GROA 115 and metapelite GROA 102 define two important age limits in the history of the Ile de Groix. Zircon and titanite LA-ICP-MS ${ }^{206} \mathrm{~Pb} /{ }^{238} \mathrm{U}$ ages for albite gneiss GROA 115 indicate a crystallisation age at $480.8 \pm 4.8 \mathrm{Ma}$, i.e., during the Early Ordovician. This age corresponds to the granitic magma emplacement, contemporaneous with the granitic to rhyolitic, pre-orogenic magmatism related to the Cambro-Ordovician continental rifting and widely recognised in the internal zones of the Variscan belt from the Polish Sudetes to the Central Iberia (e.g. Guerrot et al. 1997; Crowley et al. 2000; Ballèvre et al. 2002; Mazur et al. 2004; Bea et al. 2007; Martínez Catalán et al. 2007; Bussy et al. 2011; Ballèvre et al. 2011). Zircon crystals with late Neoproterozoic ages (c. 586-647 Ma) represent inherited grains from a Cadomian basement. Moreover, both types of 


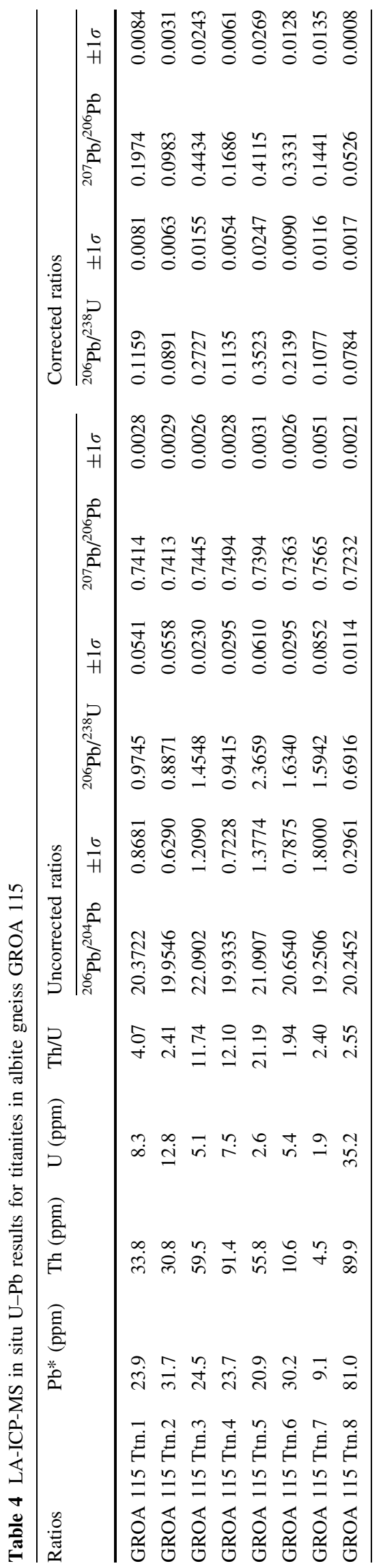

zircons are clearly distinguishable based on their morphology (Fig. 7c, d).

The titanite $\mathrm{U}-\mathrm{Pb}$ age obtained for metapelite GROA 102 indicates a late Devonian age of $366 \pm 33 \mathrm{Ma}$, which corresponds to the HP-LT peak metamorphic event, related to the early stages of the Variscan orogeny. This result corroborates the ages of 358-365 Ma obtained by Bosse et al. (2005) using the ${ }^{40} \mathrm{Ar} /{ }^{39} \mathrm{Ar}$ and $\mathrm{Rb}-\mathrm{Sr}$ methods on phengite, epidote and whole rock (metabasites and metapelites).

Geochemical signature of albite gneiss GROA 115

The presence of porphyroclastic albite and microcline, as well as metamict allanite, suggests a magmatic origin for albite gneiss GROA 115. The texture suggests that it derives from a fine-grained magmatic rock, i.e., either a microgranitic dyke or a porphyritic lava or tuff of rhyolitic composition. Albite gneiss GROA 115 (a and b) presents characteristic features of S-type peraluminous granites (A/ CNK 1.5; high $\mathrm{SiO}_{2}$; high LILE content) (Lachlan granodiorite, Maas et al. 1997; Velay leucogranite, Williamson et al. 1997; Saint-Malo anatectic granite; Milord et al. 2001).

The peraluminous signature would suggest that the felsic magma derives from melting of a metasedimentary peraluminous basement and was emplaced in a collisional context (S-type granites; Chappell and White 1974) during the thermal relaxation related to the exhumation of an orogen (England and Thompson 1984). The peraluminous character of albite gneiss GROA 115 is unequivocal, but the interaction with subduction-related metamorphic fluids produced during the dehydration of the surrounding rocks (micaschists or, to a lesser extent, metabasites) can be responsible for the mobilisation and transport of $\mathrm{K}_{2} \mathrm{O}$ and $\mathrm{Na}_{2} \mathrm{O}$ contents and consequently for the increase in the A/CNK ratio. Albite gneiss GROA 115 derives from a volcanic tuff or a microgranitic dyke rather than from a massive granitoid. It may have been more porous and more permeable to fluids during metamorphism, resulting in high fluid-rock ratios. Rocks that have undergone high fluidrock ratios on the Ile de Groix generally show evidences of local mass transfers (El Korh et al. 2011). The replacement of biotite by chlorite also releases $\mathrm{K}_{2} \mathrm{O}$, resulting in a lower whole rock $\mathrm{K}_{2} \mathrm{O}$ content and a higher $\mathrm{A} / \mathrm{CNK}$ ratio.

The negative $\mathrm{Eu}$ and $\mathrm{Sr}$ anomalies and the slight MREE depletion indicate fractionation of plagioclase and probably apatite in the magma. The Th anomaly is related to the presence of metamict allanite. The high HREE and Y contents argue against a garnet-bearing residue during partial melting. However, the high $\mathrm{Al}_{2} \mathrm{O}_{3}$ and $\mathrm{SiO}_{2}$ contents, as well as rather high $\mathrm{Fe}_{2} \mathrm{O}_{3}$ and $\mathrm{MgO}$ contents compared to the $\mathrm{SiO}_{2}$ content, suggest that cordierite may 


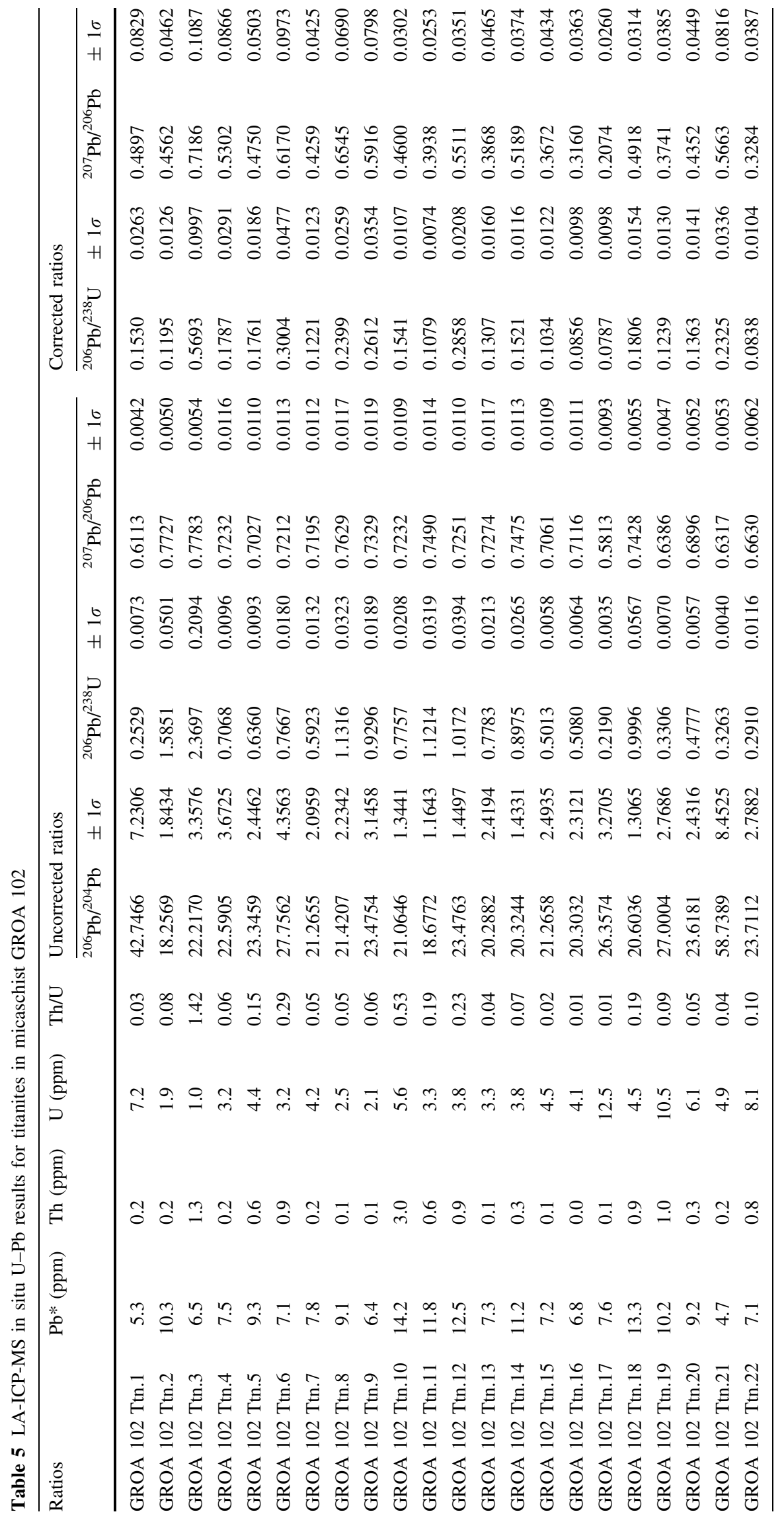


Fig. 9 Tera-Wasserburg plots of $\mathrm{Pb}$ uncorrected (a) and corrected (b) LA-ICP-MS U-Pb data for titanite in micaschist GROA 102

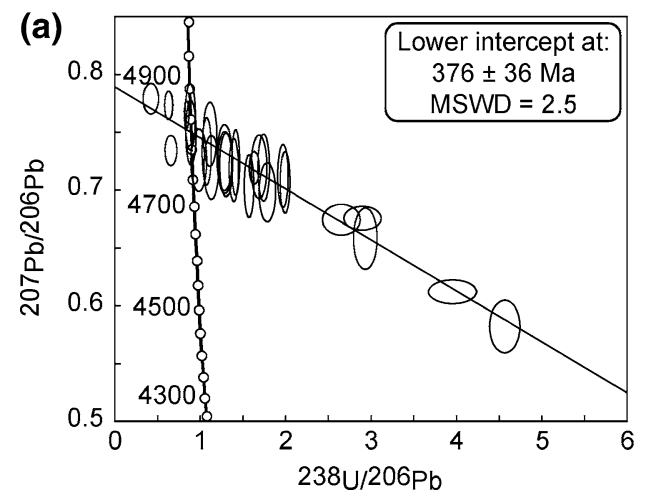

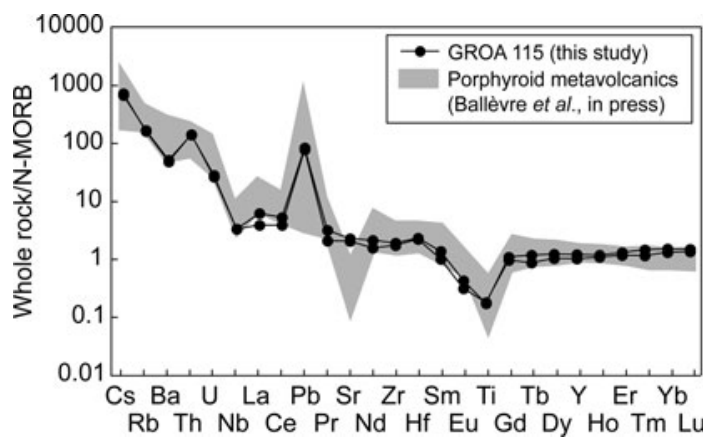

Fig. 10 N-MORB-normalised multi-element diagrams illustrating the whole-rock trace element compositions of albite gneiss GROA 115 in comparison with the metavolcanics of the "Porphyroid Nappe" (Ballèvre et al. 2011). Normalisation values are from Sun and McDonough (1989). Grey regions correspond to the composition of the Porphyroid metavolcanics

have been present in the protolith of albite gneiss GROA 115, implying the partial melting of a pelitic source (e.g., the Brioverian sediments from the Cadomian basement) at relatively low pressure (see Williamson et al. 1997).

However, the trace element geochemistry of albite gneiss GROA 115 also indicates similarities with the backarc I-type and anorogenic A-type granite chemistry (MORB-like flat HREE distribution, moderate $\mathrm{Y}+\mathrm{Nb}$ values; high $\mathrm{U}$ and $\mathrm{Th}$ values; negative $\mathrm{Nb}$ and $\mathrm{Ti}$ anomalies). Anorogenic granites characteristic of geodynamic setting with lithosphere extension also sometimes occur as weakly peraluminous (Bucher and Frost 2006). Moreover, the presence of allanite and titanite as accessory minerals rather suggests an anorogenic or a volcanic arc origin. The morphological types of zircon grains corroborate this hypothesis. Ordovician zircons belong to the P1-P5 types of Pupin (1980) indicating an alkaline to tholeiitic I-type magma, common in extensional, anorogenic or back-arc settings, even if the $\mathrm{Al} /(\mathrm{Na}+\mathrm{K})$ ratio is about 2.3. The peraluminous signature of albite gneiss GROA 115 probably results from a crustal contamination due to the interaction of an upwelling mantle-derived magma with the Cadomian basement. The LILE enrichment and depletion of $\mathrm{Nb}, \mathrm{Ta}$ and $\mathrm{Ti}$ indicate a magma with a depleted mantle signature, which was modified by a variable crustal contribution or by a subduction component (Pearce et al. 1984; Harris et al. 1986). The crustal contamination is also suggested by similarities in major and rare-earth element compositions of albite gneiss GROA 115 and A-type granites resulting from the mixing of a mantle-derived magma and a crustal magma (Finnish wiborgite rapakivi granite and Spirit Mountain granite; Haapala et al. 2005). Cadomian and older inherited zircons are of S2 and S10-15 types, generally found in calc-alkaline or S-type magmas, related to arc volcanism or orogenic plutonism.

Albite gneiss GROA 115 is contemporaneous with the felsic volcanic rocks from the South Armorican Domain (the "Porphyroid Nappe"; Le Hébel et al. 2002a, b; Ballèvre et al. 2011) and shows similar chemical characteristics. The porphyroids are metamorphic rocks deriving from rhyolitic to dacitic porphyritic lavas (Boyer 1974; Le Hébel et al. 2002a) formed during the Early Ordovician rifting (473-494 Ma; Ballèvre et al. 2011). They display the general characteristics of orogenic calcalkaline series and were interpreted as the result of the partial melting of a sedimentary or igneous source (Ballèvre et al. 2011). The similarity between the felsic metavolcanics (Porphyroid Nappe) and albite gneiss GROA 115 (Fig. 10) suggests that they are both related to the same volcanic event.

Different studies have observed that pre-Variscan granitic rocks related to the Cambro-Ordovician felsic plutonism generally show a large spectrum of compositions from calc-alkaline subduction-related granite, to anorogenic alkaline granites and collisional S-type granites (Guerrot et al. 1997; Crowley et al. 2000; Ballèvre et al. 2002; Mazur et al. 2004; Bea et al. 2007). Bea et al. (2007) demonstrated that Cambro-Ordovician calc-alkaline to peraluminous magmas in Central Iberia were emplaced in a continental rift environment and inherited their signature from a fast melting of their late Pan-African protolith, even if they show subduction-related characteristics. In the Northern Bohemian Massif, the Early Palaeozoic granitic plutonism is supposed to derive from partial melting of the 
Cadomian basement (Crowley et al. 2000). Their signature has been inherited from the composition of their protolith (Klimas-August 1990; Floyd et al. 2000). Crowley et al. (2000) suggested that the granitic magmas were emplaced by mantle plume convection, which was responsible for the fragmentation of the northern Gondwana margin and the formation of microplates because of a widespread tensional regime related to the formation of rift-related basalts. Similarly, the magmatic protolith of albite gneiss GROA 115, emplaced during the Cambro-Ordovician continental rifting, may have inherited its specific chemical composition (i.e., combination of orogenic, back-arc and anorogenic signatures) from the partial melting of the Cadomian basement, documented by the inherited cores in the studied zircons, in an extensional context, like a back-arc spreading setting, possibly due to the upwelling of a mantle-derived magma. The partial melting of the pelitic Cadomian basement may have been triggered by upwelling of a mantle-derived magma, leading to the formation of an $\mathrm{Al}_{2} \mathrm{O}_{3}$-rich felsic magma. The felsic magma is expected to have mixed with the basic magma before rising towards the surface.

\section{Continent to ocean transition in the Ile de Groix}

\section{Cambro-Ordovician rifting}

Magmatic rocks of the Ile de Groix essentially consist of mafic metavolcanic rocks, derived from MORB-type basalts and now represented by the HP-LT metabasalts (El Korh et al. 2009). A very small amount of felsic metavolcanics, here described for the first time, records another type of magma, dated at $480 \mathrm{Ma}$. However, there are no evidences if the felsic and mafic magmatic events are contemporaneous (as appears quite probable according to the field relations) or if the basaltic magmatism represents a later event with respect to the felsic magmatism. The first hypothesis is favoured here because (1) field relations suggest that the metabasites could derive from either lava flows or sills (massive blueschists) and epiclastic sediments (banded blueschists), and (2) the albite gneiss is interpreted as a tuff, in which case its age is similar to the mafic and pelitic rocks. Alternatively, the Ile de Groix could represent part of a true oceanic crust, located close to the palaeomargin. In this case, the amount of continent-derived sediments can be relatively high. Inputs of volcanic material (tuffs) interlayered within the detrital sediments were possible when intense explosive eruptions took place on the nearby continent.

The Ile de Groix has been interpreted as a klippe (Fig. 1), which was thrust upon the "Porphyroid Nappe" (Le Hébel et al. 2002a; Ballèvre et al. 2011), which are interpreted as felsic metavolcanics. Because the metavolcanics from the Porphyroid Nappe and the albite gneiss from the Ile de Groix display the same geochemistry and have the same age, one can assume either that these two units were at a close distance from each other or that the Ile de Groix represents a more evolved stage of the continental rifting, with partial melting in the mantle overtaking the partial melting in the lower Cadomian continental crust, possibly in a back-arc setting. According to its position within pelitic sediments and to its protolith age (ca. $480 \mathrm{Ma}$ ), the albite gneiss could represent a witness of the felsic magmatism related to the Ordovician continental rifting that has been widely recognised in the internal zones of the Variscan belt. It is associated with the opening of the Rheic Ocean in the northern Gondwana margin and with the closure of the Iapetus Ocean (or ProtoThetys) during the Cambrian (550-490 Ma) (e.g. Guerrot et al. 1997; Crowley et al. 2000; Matte 2001; Ballèvre et al. 2002; von Raumer et al. 2002; Mazur et al. 2004; Schulz et al. 2004; Bea et al. 2007; Martínez Catalán et al. 2007; von Raumer and Stampfli 2008; Bussy et al. 2011; Stampfli et al. 2011; Ballèvre et al. 2011). The felsic magmatism was followed by a back-arc spreading and by the opening of the Rheic Ocean during the Early Ordovician (for discussion, see von Raumer et al. 2002; von Raumer and Stampfli 2008). The rift evolved to an intracontinental basin, where pelitic sedimentation took place. At the same time, explosive volcanism continued and produced volcanic rocks and tuffs, which were deposited in the basin. The thinning of the lithosphere has furthered the basic magma to rise towards the surface, and consequently, the felsic magmatism was followed by the emplacement of MORBtype basalts, now represented by the HP-LT metabasalts of the Ile de Groix (El Korh et al. 2009).

The compressive regime responsible for the closure of the Rheic ocean at c. 440-420 Ma led to the back-arc opening of the Palaeo-Thetys between the Galatian terranes (including the microcontinent Armorica) and the Gondwana (von Raumer and Stampfli 2008; Stampfli et al. 2011), while the Hanseatic arc detached from Laurussia (Eurasia) collided with the Galatian terranes during the late Devonian (Stampfli et al. 2011) on the opposite margin of the Rheic ocean. According to the imbrication model of Martínez Catalán et al. (2007), the Ile de Groix rocks could represent a witness of the Rheic Ocean subducted along the palaeomargin of Armorica. An alternative model suggests that the Ile de Groix metabasites could be the witnesses of the Galicia-South Brittany Ocean opened within Armorica and the Gondwana at the same time as the Rheic Ocean (Matte 2001; Bea et al. 2007). However, the Galicia-South Brittany Ocean could also represent a marginal basin within the Galatian terranes, resulting from the fragmentation of the northern Gondwana margin during the Early Palaeozoic (see Crowley et al. 2000). 


\section{Late Devonian subduction}

At the beginning of the Variscan orogeny (c. 370-360 Ma), the ocean closed in a subduction zone now recorded by the HP-LT rocks of the Ile de Groix. Subduction of the oceanic lithosphere resulted in an imbrication of its uppermost part, essentially made of metabasalts and metapelites. The titanite $\mathrm{U}-\mathrm{Pb}$ age obtained for micaschist GROA 102 indicates an age of $366 \pm 33 \mathrm{Ma}$, which corresponds to the HP-LT peak metamorphic event. This result is in agreement with the ages of 358-365 Ma obtained by Bosse et al. (2005) using the $40 \mathrm{Ar} / 39 \mathrm{Ar}$ and $\mathrm{Rb}-\mathrm{Sr}$ methods on phengite, epidote and whole rock (metabasites and metapelites). This process was accompanied by extensive folding and shearing, recorded by top-to-the South kinematic criteria (Philippon et al. 2009).

Depending upon the assumed model for the Ile de Groix, this episode can be reconstructed as follows. If the Ile de Groix was being located in the true oceanic domain, one has to assume that the oceanic lithosphere was subducted. This resulted in the imbrication of its uppermost part, essentially made of metabasalts and metapelites, the latter being sheared off the subducting lower part (gabbros, peridotites). Alternatively, the Ile de Groix could represent the distal part of the Armorican palaeomargin, with a décollement of the pile of sediments and basaltic lavas from their strongly attenuated Cadomian basement. The final result is a complex imbrication of metabasalts and metapelites in an accretionary prism.

\section{Conclusions}

The U-Pb geochronological data obtained on zircon and titanite from albite gneiss GROA 115 and metapelite GROA 102 place time constraints on the geodynamical history of the Ile de Groix. Our results allow for the first time dating the protolith of an albite orthogneiss discovered on the Ile de Groix and emplaced before the HP-LT metamorphism. The albite gneiss certainly derived from a peraluminous rock, probably a volcanic tuff, which formed during the Early Ordovician (at $480.8 \pm 4.8 \mathrm{Ma}$ ). Despite a geochemical signature similar to peraluminous orogenic magmas, the magma was emplaced during the Cambro-Ordovician continental rifting. It acquired its specific chemical composition from a combination of orogenic, back-arc and anorogenic signatures from the partial melting of the Cadomian basement, as evidenced by the presence of inherited zircons of late Neoproterozoic age (c. 586-647 Ma). HP-LT metabasites outcropping on the Ile de Groix constitute the remnants of an oceanic basin, whose closure resulted in the collision between the microcontinent Armorica and the northern margin of the Gondwana during the late Devonian.
Acknowledgments Field work has been allowed by the Scientific Committee of the Réserve Naturelle Nationale François Le Bail. Thanks to Fabio Capponi for providing XRF analyses and to Rossana Martini and Agathe Martignier for assistance with the SEM analyses. We are grateful to Larry Heaman for providing the Khan titanite standard and to Daniel Condon for providing the Fish Canyon Tuff titanite standard. Thanks to Catherine Robert for her help with the sampling on the island. Discussions with Blair Schoene, Maria Ovtcharova and Urs Schaltegger at various stages of this study were much appreciated. Constructive reviews of Jürgen von Raumer and Bernhard Schulz helped us to improve the earlier version of this manuscript. The editorial work of Wolf-Christian Dullo and Ingo Braun was greatly appreciated. The research was supported by project Nr. 20021-113280 of the Swiss National Science Foundation to S.Th. Schmidt and T.W. Vennemann.

\section{References}

Altherr R, Siebel W (2002) I-type plutonism in a continental back-arc setting: Miocene granitoids and monzonites from the central Aegean Sea, Greece. Contrib Mineral Petrol 143:397-415

Arenas R, Martínez Catalán JR, Sánchez Martínez S, FernándezSuárez J, Andonaegui P, Pearce JA, Corfu F (2007) The vila de Cruces Ophiolite: a remnant of the early Rheic Ocean in the Variscan suture of Galicia (Northwest Iberian Massif). J Geol 115:129-148

Audren C, Lefort JP (1977) Géologie du plateau continental sud armoricain entre les îles de Glénan et de Noirmoutier. Implications geodynamiques. Bull Soc Géol France 7(XIX):395-404

Audren C, Triboulet C, Chauris L, Lefort JP, Vigneresse JL, Audrain J, Thiéblemont D, Goyallon J, Jégouzo P, Guennoc P, Augris C, Carn A (1993) Notice explicative de la feuille Ile de Groix à 1/25000 (carte géologique). BRGM, Orléans

Azor A, Rubatto D, Simancas JF, Lodeiro FG, Martínez Poyatos D, Martín Parra LM, Matas J (2008) Rheic Ocean ophiolitic remnants in southern Iberia questioned by SHRIMP U-Pb zircon ages on the Beja-Acebuches amphibolites. Tectonics 27 TC5006 doi:10.1029/2008TC002306

Ballèvre M, Paris F, et Robardet M (1992) Corrélations ibéroarmoricaines au Paléozoïque : confrontation des données paléobiogéographiques et tectonométa-morphiques. CR Acad Sci Paris (II) 315:1783-1789

Ballèvre M, Bosse V, Gapais D (1998) Les schistes bleus de l'île de Groix (Massif armoricain): un paléoprisme d'accrétion. Réunion des Sciences de la Terre XVII, Brest, Soc Géol France ed., Paris, pp 66-67

Ballèvre M, Le Goff E, Hébert R (2001) The tectonothermal evolution of the Cadomian belt of northern Brittany, France: a Neoproterozoic arc. Tectonophysics 331:19-43

Ballèvre M, Capdevila R, Guerrot C, Peucat JJ (2002) Discovery of an alkaline orthogneiss in the eclogite-bearing cellier unit (Champtoceaux Complex, Armorican Massif): a new witness of the Ordovician rifting. CR Geosci 334:303-311

Ballèvre M, Pitra P, Bohn M (2003) Lawsonite growth in the epidote blueschists from the Ile de Groix (Armorican massif, France): a potential geobarometer. J Metam Geol 21:723-735

Ballèvre M, Bosse V, Ducassou C, Pitra P (2009) Palaeozoic history of the Armorican Massif: models for the tectonic evolution of the suture zones. CR Geosci 341:174-201

Ballèvre M, Fourcade S, Capdevila R, Peucat JJ, Cocherie A, Fanning CM (2011) Geochronology and geochemistry of the Ordovician felsic volcanism in the Southern Armorican Massif (Variscan belt, France). Implications for the breakup of Gondwana. Gondwana Res. doi:10.1016/j.gr.2011.07.030 
Bard JP (1971) Sur l'alternance des zones métamorphiques et granitiques dans le segment hercynien sud-ibérique; comparaison de la variabilité des caractères géotectoniques de ces zones avec les orogènes "orthotectoniques". Bol Geol Minero 82:321-345

Bea F, Montero P, González-Lodeiro F, Talavera C (2007) Zircon inheritance reveals exceptionally fast crustal magma generation processes in Central Iberia during the Cambro-Ordovician. J Petrol 48:2327-2339

Béchennec F, Guennoc P, Guerrot C, Lebret P, Thieblemont D (1997) Notice explicative de la feuille Concarneau à 1/50000 (carte géologique). BRGM, Orléans

Bernard-Griffiths J, Carpenter MSN, Peucat JJ, Jahn BM (1986) Geochemical and isotopic characteristics of blueschist facies rocks from the Ile de Groix, Armorican Massif (northwest France). Lithos 19:235-253

Bosse V, Ballèvre M, Vidal O (2002) Ductile thrusting recorded by the garnet isograd from blueschist-facies metapelites of the Ile de Groix, Armorican Massif, France. J Petrol 43:485-510

Bosse V, Féraud G, Ballèvre M, Peucat JJ, Corsini M (2005) Rb-Sr and 40Ar/39Ar ages in blueschists from the Ile de Groix (Armorican Massif, France): Implications for closure mechanisms in isotopic systems. Chem Geol 220:21-45

Boudier F, Nicolas A (1976) Interprétation nouvelle des relations entre tectonique et métamorphisme dans l'lle de Groix (Bretagne). Bull Soc Geol France XVIII:135-144

Boyer C (1974) Volcanismes acides paléozoïques dans le Massif armoricain, thèse, université Paris-Sud, Orsay, $384 \mathrm{p}$

Brun JP, Guennoc P, Truffert C, Vairon J (2001) Cadomian tectonics in northern Brittany: a contribution of 3-D crustal-scale modelling. Tectonophysics 331:229-246

Bucher K, Frost BR (2006) Fluid transfer in high-grade metamorphic terrains intruded by anorogenic granites: the Thor range, Antartica. J Petrol 47:567-593

Bussy F, Péronnet V, Ulianov A, Epard JL, von Raumer J (2011) Ordovician magmatism in the external French Alps: witness of a peri-gondwanan active continental margin. In: Gutiérrez-Marco JC, Rábano I, García-Bellido D (eds) Ordovician of the World. Cuadernos del Museo Geominero 14. Instituto Geológico y Minero de España, Madrid, pp 567-574

Carpenter MSN (1976) Petrogenetic study of the glaucophane schists and associated rocks from the Ile de Groix, Brittany, France. Unpublished $\mathrm{PhD}$ Thesis, Oxford University, $271 \mathrm{pp}$

Carpenter MSN, Civetta L (1976) Hercynian high pressure/low temperature metamorphism in the Ile de Groix blueschists. Nature 262:276-277

Chantraine J, Egal E, Thiéblemont D, Le Goff E, Guerrot C, Ballèvre M, Guennoc P (2001) The Cadomian active margin (North Armorican Massif, France): a segment of the North Atlantic Panafrican belt. Tectonophysics 331:1-18

Chappell BW, White AJR (1974) Two contrasting granite types. Pac Geol 8:173-174

Clark AH, Scott DJ, Sandeman HA, Bromley AV, Farrar E (1998) Siegenian generation of the Lizard ophiolite: $\mathrm{U}-\mathrm{Pb}$ zircon age for plagiogranite, Porthkerris, Cornwall. J Geol Soc Lond 155:595-598

Cogné J (1971) Le Massif armoricain et sa place dans la structure des socles ouest-européens; 1'arc hercynien ibéro-armoricain. In: Debysser J, Le Pichon X, Montadert L (Eds.), Histoire Structurale du Golfe de Gascogne vol 1, Paris, Technip, pp 1-23

Cogné J, Jeannette D, Ruhland M (1966) L'Ile de Groix: étude structurale d'une série métamorphique à glaucophane en Bretagne méridionale. Bulletin du Service de la Carte Géologique d'Alsace-Lorraine 19:41-95

Crowley QG, Floyd PA, Winchester JA, Franke W, Holland JG (2000) Early Paleozoic rift-related magmatism in Variscan
Europe: fragmentation of the Armorican Terrane Assemblage. Terra Nova 12:171-180

Díaz Garcia F, Arenas R, Martínez Catalán JR, González del Tánago J, Dunning GR (1999) Tectonic evolution of the Careón Ophiolite (Northwest Spain): a remnant of oceanic lithosphere in the Variscan belt. J Geol 107:587-605

Djro SC, Triboulet C, Audren C (1989) Les chemins pressiontempérature-temps-déformation-espace $(\mathrm{P}-\mathrm{T}-\mathrm{t}-\mathrm{d}-\mathrm{e})$ dans les micaschistes associés aux schistes bleus de l'île de Groix, Bretagne Méridionale, France. Schweiz Mineral Petrogr Mitt 69:73-90

El Korh A (2006) Métamorphisme HP-BT dans les métabasites de l'Ile de Groix, France: étude pétrologique et géochimique. Unpublished Master Thesis, University of Geneva, $334 \mathrm{pp}$

El Korh A (2010) Geochemical fingerprints of devolatilisation reactions in the high-pressure rocks of Ile de Groix, France. PhD Thesis, University of Geneva, Terre et Environnement 99, $361 \mathrm{pp}$

El Korh A, Schmidt STh, Ulianov A, Potel S (2009) Trace element partitioning in HP-LT metamorphic assemblages during subduction-related metamorphism, Ile de Groix, France: a detailed LA-ICP-MS study. J Petrol 50:1107-1148

El Korh A, Schmidt STh, Vennemann T, Ulianov A (2011) Trace element and O-isotope composition of polyphase metamorphic veins of the Ile de Groix (Armorican Massif, France): implication for fluid flow during HP subduction and exhumation processes. In: Dobrzhinetskaya L, Faryad W, Wallis S, Cuthbert $\mathrm{S}$ (eds) Ultrahigh pressure metamorphism: 25 years after discovery of coesite and diamond. Elsevier, Amsterdam, pp 243-291

England PC, Thompson AB (1984) Pressure-temperature-time paths of regional metamorphism; I. Heat transfer during the evolution of regions of thickened continental crust. J Petrol 25:894-928

Floyd PA, Winchester JA, Seston R, Kryza R, Crowley QG (2000) Review of geochemical variation in Lower Palaeozoic metabasites from the NE Bohemian Massif: intracratonic rifting and plume-ridge interaction. In: Franke W, Haak V, Oncken O, Tanner D (eds.) Orogenic processes: quantification and modelling in the Variscan Belt. Geol Soc Lond Spec Pub 179:155-174

Frost BR, Chamberlain KR, Schumacher JC, Scott DJ, Moser DE (2000) Sphene (titanite); phase relations and role as a geochronometer. Chem Geol 172:131-148

Frost BR, Barnes CG, Collins WJ, Arculus RJ, Ellis DJ, Frost CD (2001) A geochemical classification of granitic rocks. J Petrol 42:2033-2048

Gapais D, Lagarde JL, Le Corre C, Audren C, Jégouzo P, Casas Sainz A, Van Den Driessche J (1993) La zone de cisaillement de Quiberon: témoin d'extension de la chaîne varisque en Bretagne méridionale au Carbonifère. Comptes Rendus de l'Académie des Sciences de Paris II 316:1123-1129

Guerrot C, Béchennec F, Thiéblemont D (1997) Le magmatisme paléozoïque de la partie nord-ouest du domaine nord-armoricain: données géochronologiques nouvelles. Comptes-Rendus de l'Académie des Sciences de Paris (IIa) 324:977-984

Guillocheau F, Rolet J (1982) La sédimentation paléozoïque ouestarmoricaine. Histoire sédimentaire; relations tectonique-sédimentation. Bulletin de la Société Géologique et Minéralogique de Bretagne (C) 14:45-62

Haapala I, Rämö OT, Frindt S (2005) Comparison of Proterozoic and Phanerozoic rift related basaltic-granitic magmatism. Lithos 80:1-32

Harris NBW, Pearce JA, Tindle AG (1986) Geochemical characteristics of collision-zone magmatism. In: Coward MP, Ries AC (eds), Collision Tectonics 19, Geol Soc Lond Spec Pub, pp 67-81

Heaman L (2009) The application of U-Pb geochronology to mafic, ultramafic and alkaline rocks: an evaluation of three mineral standards. Chem Geol 261:43-52 
Jackson SE, Pearson NJ, Griffin WL, Belousova EA (2004) The application of laser ablation-inductively coupled plasma-mass spectrometry to in situ $\mathrm{U}-\mathrm{Pb}$ zircon geochronology. Chem Geol 211:47-69

Jégouzo P, Peucat JJ, Audren C (1986) Caractérisation et signification géodynamique des orthogneiss calcoalcalins d'âge ordovicien de Bretagne méridionale. Bull Soc Géol France (8) II, pp 839-848

Klimas-August K (1990) Genesis of gneisses and granites from the eastern part of the Izera metamorphic complex in the light of studies on zircons from selected geological profiles. Geol Sudetica 24:1-71

Kretz R (1983) Symbols for rock-forming minerals. Am Mineral 68:277-279

Kryza R, Pin C (2010) The central-sudetic ophiolites (SW Poland): petrogenetic issues, geochronology and palaeotectonic implications. Gondwana Res 17:292-305

Le Corre C (1977) Le Briovérien de Bretagne centrale: essai de synthèse lithologique et structurale. Bull Bur Rech Géol Min I (3), pp 219-254

Le Hébel F, Vidal O, Kiénast JR, Gapais D (2002a) Les « Porphyroïdes » de Bretagne méridionale: une unité de HP-BT dans la chaîne Hercynienne. CR Geosci 334:205-211

Le Hébel F, Gapais D, Fourcade S, Capdevila R (2002b) Fluidassisted large strains in a crustal-scale décollement (Hercynian belt of South Brittany, France). In: De Meer S, Drury MS, De Bresser JHP, Pennock GM (Eds.), Deformation mechanisms, rheology and tectonics: current status and future perspectives. Geol Soc Lond Spec Pub 200:85-101

López-Carmona A, Abati J, Reche J (2010) Petrologic modelling of chloritoid-glaucophane schists from the NW Iberian Massif. Gondwana Res 17:377-391

Ludwig KR (2003) Isoplot 3.0: a geochronological toolkit for Microsoft Excel. Berkeley Geochronology Center Special Publication $4,71 \mathrm{p}$

Maas R, Nicholls IA, Legg C (1997) Igneous and metamorphic enclaves in the S-type Deddick granodiorite, Lachlan Fold Belt, SE Australia: petrographic, geochemical and $\mathrm{Nd}-\mathrm{Sr}$ isotopic evidence for crustal melting and magma mixing. J Petrol $38: 815-841$

Maluski H (1976) Intérêt de la méthode 40Ar/39Ar pour la datation des glaucophanes. Exemple des glaucophanes de l'île de Groix. Comptes-rendus de l'Académie des Sciences de Paris (D) 283:223-226

Martínez Catalán JR, Arenas R, Díaz García F, González Cuadra P, Gómez-Barreiro P, Abati J, Castiñeiras P, Fernández-Suárez S, Sánchez Martínez S, Andonaegui P, González Clavijo E, Díez Montes A, Rubio Pascual FJ, Valle Aguado B (2007) Space and time in the tectonic evolution of the northwestern Iberian Massif. Implications for the Variscan belt. Geol Soc Am Mem 200:403423

Matte P (2001) The Variscan collage and orogeny (480-290 Ma) and the tectonic definition of the Armorica microplate: a review. Terra Nova 13:122-128

Mazur S, Turniak K, Bröcker M (2004) Neoproterozoic and CambroOrdovician magmatism in the Variscan Klodzko Metamorphic Complex (West Sudetes, Poland): new insights from $\mathrm{U} / \mathrm{Pb}$ zircon dating. Int J Earth Sci 93:758-772

Ménot RP, Peucat JJ, Scarenzi D, Piboule M (1988) 496-My age of plagiogranites in the Chamrousse ophiolite complex (external crystalline massifs in the French Alps)-evidence of a lower Paleozoic oceanization. Earth Planet Sci Lett 88:82-92

Milord I, Sawyer EW, Brown M (2001) Formation of diatexite migmatite and granite magma during anatexis of semi-pelitic metasedimentary rocks: an example from St. Malo, France. J Petrol 42:487-505
Nance RD, Gutiérrez-Alonso G, Keppie JD, Linnemann U, Murphy JB, Quesada C, Strachan RA, Woodcock NH (2010) Evolution of the Rheic Ocean. Gondwana Res 17:194-222

Pearce JA (1983) Role of the sub-continental lithosphere in magma genesis at active continental margins. In: Hawkesworth CJ, Norry MJ (eds) Continental basalts and mantle xenoliths. Shiva, Nantwich, pp 230-249

Pearce JA, Harris NBW, Tindle AG (1984) Trace element discrimination diagrams for the tectonic interpretation of granitic rocks. J Petrol 25:956-983

Pearce NJG, Perkins WT, Westgate JA, Gorton MP, Jackson SE, Neal CR, Chenery SP (1997) A compilation of new and published major and trace element data for NIST SRM 610 and NIST SRM 612 glass reference materials. Geostand Newsl 21:115-144

Peucat JJ (1986) Rb-Sr and U-Pb dating of the blueschists of the Ile de Groix. In: Evans BW, Brown EH (eds), Blueschists and eclogites, Geol Soc Am Mem 164:229-238

Peucat JJ, Cogné J (1977) Geochronology of some blueschists from ile de Groix, France. Nature 268:131-132

Philippon M, Brun JP, Gueydan F (2009) Kinematic records of subduction and exhumation in the Ile de Groix blueschists (Hercynian belt; Western France). J Struct Geol 31:1308-1321

Pin C, Carme F (1987) A Sm-Nd isotopic study of 500 Ma old oceanic crust in the Variscan belt of Western Europe-the Chamrousse ophiolite complex, Western Alps (France). Contrib Mineral Petrol 96:406-413

Pin C, Paquette JL, Santos Zalduegui JF, Gil Ibarguchi JI (2002) Early Devonian suprasubduction-zone ophiolite related to incipient collisional processes in the Western Variscan Belt: The Sierra de Careón unit, Ordenes Complex, Galicia. Geol Soc Am Spe Pap 364:57-71

Plank T, Langmuir CH (1998) The chemical composition of subducting sediment and its consequences for the crust and mantle. Chem Geol 145:325-394

Pupin JP (1980) Zircon and granite petrology. Contrib Mineral Petrol 73:207-220

Quinquis H (1980) Schistes bleus et déformation progressive: l'exemple de l'île de Groix. Thèse de 3ème cycle, Université de Rennes, $145 \mathrm{pp}$

Quinquis H, Choukroune P (1981) Les schistes bleus de l'île de Groix dans la chaîne hercynienne: implications cinématiques. Bulletin de la Société Géologique de France (7) XXIII:409-418

Robardet M (1981) Evolution géodynamique du Nord-est du Massif armoricain au Paléozoïque Mém Soc Géol Min Bretagne 20, $342 \mathrm{pp}$

Rodríguez Aller J (2005) Recristalización y deformación de litologías supracorticales sometidas a metamorfismo de alta presión (Complejo de Malpica-Tuy, NO del Macizo Ibérico). Nova Terra 29:1-572

Sánchez Martínez S, Arenas R, Díaz García FD, Martínez Catalán JR, Gómez-Barreiro J, Pearce JA (2007) Careón ophiolite, NW Spain: suprasubduction zone setting for the youngest Rheic Ocean floor. Geology 35:53-56

Schmitz MD, Bowring SA (2001) U-Pb zircon and titanite systematics of the Fish Canyon Tuff: an assessment of high-precision $\mathrm{U}-\mathrm{Pb}$ geochronology and its application to young volcanic rocks. Geochim Cosmochim Acta 65:2571-2587

Schulz B, Triboulet C, Audren C, Pfeifer HR, Gilg A (2001) Twostage prograde and retrograde Variscan metamorphism of glaucophane-eclogites, blueschists and greenschists from the Ile de Groix (Brittany, France). Int J Earth Sci 90:871-889

Schulz B, Bombach K, Pawlig S, Brätz H (2004) Neoproterozoic to Early-Palaeozoic magmatic evolution in the Gondwana-derived Austroalpine basement to the south of the Tauern Window (Eastern Alps). Int J Earth Sci 93:824-843 
Simonetti A, Heaman LM, Chacko T, Banerjee NR (2006) In situ petrographic thin section $\mathrm{U}-\mathrm{Pb}$ dating of zircon, monazite, and titanite using laser ablation MC-ICP-MS. Int J Mass Spectr 253:87-97

Stacey JS, Kramers JD (1975) Approximation of terrestrial lead isotope evolution by a two-stage model. Earth Planet Sci Lett 26(2):207-221

Stampfli GM, von Raumer J, Wilhem C (2011) The distribution of Gondwana-derived terranes in the early paleozoic. In: GutiérrezMarco JC, Rábano I, García-Bellido D (eds) Ordovician of the world. Cuadernos del Museo Geominero 14. Instituto Geológico y Minero de España, Madrid, pp 567-574

Storey CD, Jeffries TE, Smith M (2006) Common lead-corrected laser ablation ICP-MS U-Pb systematics and geochronology of titanite. Chem Geol 227:37-52

Sun SS, McDonough WF (1989) Chemical and isotopic systematics of oceanic basalts: implications for mantle composition and processes. In: Saunders AD, Norry MJ (eds), Magmatism in ocean basins, Geol Society Lond Spec Pub 42:313-345

Taylor SR, McLennan SM (1981) The composition and evolution of the continental crust: rare earth element evidence from sedimentary rocks. Phil Trans R Soc Lond A301:381-399
Tera F, Wasserburg GJ (1972) U-Th-Pb systematics in three Apollo 14 basalts and the problem of initial $\mathrm{Pb}$ in lunar rocks. Earth Planet Sci Lett 14:281-304

Triboulet C (1974) Les glaucophanites et roches associées de l'île de Groix (Morbihan, France): étude minéralogique et pétrogénétique. Contrib Mineral Petrol 45:65-90

Valverde-Vaquero P, Dunning CR (2000) New U-Pb ages for the early ordovician magmatism in central Spain. J Geol Soc Lond 157:15-26

von Raumer J, Stampfli GM (2008) The birth of the Rheic Oceanearly palaeozoic subsidence patterns and tectonic plate scenarios. Tectonophysics 461:9-20

von Raumer JF, Stampfli GM, Borel G, Bussy F (2002) Organization of pre-Variscan basement areas at the north-Gondwanan margin. Int J Earth Sci 91:35-52

Wiedenbeck M, Allé P, Corfu F, Griffin WL, Meier M, Oberli F, von Quadt A, Roddick JC, Spiegel W (1995) Three nature zircon standards for $\mathrm{U}-\mathrm{Th}-\mathrm{Pb}, \mathrm{Lu}-\mathrm{Hf}$, trace element and $\mathrm{REE}$ analyses. Geostand Newsl 19:1-23

Williamson BJ, Downes H, Thirlwall MF, Beard A (1997) Geochemical constraints on restite composition and unmixing in the Velay anatectic granite, French Massif Central. Lithos 40:295-319 